\title{
Simulating carbon exchange using a regional atmospheric model coupled to an advanced land-surface model
}

\author{
H. W. Ter Maat ${ }^{1}$, R. W. A. Hutjes ${ }^{1}$, F. Miglietta ${ }^{2}$, B. Gioli ${ }^{2}$, F. C. Bosveld ${ }^{3}$, A. T. Vermeulen ${ }^{4}$, and H. Fritsch ${ }^{5, *}$ \\ ${ }^{1}$ ESS-CC (Earth System Science-Climate Change), Alterra - Wageningen UR, Wageningen, The Netherlands \\ ${ }^{2}$ IBIMET, Via Giovanni Caproni 8, Florence, 50145, Italy \\ ${ }^{3}$ Royal Netherlands Meteorological Institute, De Bilt, The Netherlands \\ ${ }^{4}$ Energy Research Centre of the Netherlands (ECN), Department of Air Quality and Climate Change, \\ Petten, The Netherlands \\ ${ }^{5}$ Max-Planck Institute for Biogeochemistry, Jena, Germany \\ *now at: Jena-Optronik, Jena, Germany
}

Received: 28 July 2008 - Published in Biogeosciences Discuss.: 29 October 2008

Revised: 8 June 2010 - Accepted: 11 June 2010 - Published: 16 August 2010

\begin{abstract}
This paper is a case study to investigate what the main controlling factors are that determine atmospheric carbon dioxide content for a region in the centre of The Netherlands. We use the Regional Atmospheric Modelling System (RAMS), coupled with a land surface scheme simulating carbon, heat and momentum fluxes (SWAPS-C), and including also submodels for urban and marine fluxes, which in principle should include the dominant mechanisms and should be able to capture the relevant dynamics of the system. To validate the model, observations are used that were taken during an intensive observational campaign in central Netherlands in summer 2002. These include flux-tower observations and aircraft observations of vertical profiles and spatial fluxes of various variables.

The simulations performed with the coupled regional model (RAMS-SWAPS-C) are in good qualitative agreement with the observations. The station validation of the model demonstrates that the incoming shortwave radiation and surface fluxes of water and $\mathrm{CO}_{2}$ are well simulated. The comparison against aircraft data shows that the regional meteorology (i.e. wind, temperature) is captured well by the model. Comparing spatially explicitly simulated fluxes with aircraft observed fluxes we conclude that in general latent heat fluxes are underestimated by the model compared to the observations but that the latter exhibit large variability within all flights. Sensitivity experiments demonstrate the relevance of the urban emissions of carbon dioxide for the carbon balance
\end{abstract}

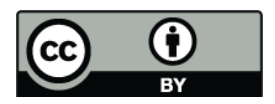

Correspondence to: $\mathrm{H}$. W. Ter Maat (herbert.termaat@wur.nl) in this particular region. The same tests also show the relation between uncertainties in surface fluxes and those in atmospheric concentrations.

\section{Introduction}

A large mismatch exists between our understanding and quantification of ecosystem atmosphere exchange of carbon dioxide at the local scale and that at the continental scale. In this paper we address some of the complexities emerging at intermediate scales.

Inverse modelling with global atmospheric tracer transport models has been used to obtain the magnitude and distribution of regional $\mathrm{CO}_{2}$ fluxes from variations in observed atmospheric $\mathrm{CO}_{2}$ concentrations. However, according to Gurney et al. (2002) no consensus has yet been reached using this method and more recent "progress" in inversion modelling developments paradoxically has led to more divergent estimations. Gerbig et al. (2003) suggests that models require a horizontal resolution smaller than $30 \mathrm{~km}$ to resolve spatial variation of atmospheric $\mathrm{CO}_{2}$ in the boundary layer over the continent.

At the local scale, eddy-flux observation sites throughout the world are trying to estimate the carbon exchange of various ecosystems within reasonable accuracy (e.g. Valentini et al., 2000; Janssens et al., 2003). These surface fluxes show a large variability over various vegetated areas. Together with the vertical mixing in the atmosphere, these surface fluxes vary diurnally and seasonally, leading to the rectifier effect, which is difficult to capture in large scale transport models

Published by Copernicus Publications on behalf of the European Geosciences Union. 
(Denning et al., 1995, 1999). Earlier studies (e.g. Bakwin et al., 1995) showed also the importance of processes like fossil fuel emission and biospheric uptake on the amplitude and magnitude of diurnal and seasonal cycles of $\mathrm{CO}_{2}$ concentration $\left(\left[\mathrm{CO}_{2}\right]\right)$.

The hypothesis is that the uncertainties mentioned before can be reduced at the regional level if a good link between local and global scale can be established. A critical role at the regional level is played by the planetary boundary layer (PBL) dynamics influencing the transport of $\mathrm{CO}_{2}$ away from the biospheric and anthropogenic sources at the surface. PBL processes that influence the local $\mathrm{CO}_{2}$ concentration are: entrainment of free tropospheric $\mathrm{CO}_{2}$ (de Arellano et al., 2004); subsidence; lateral advection of air containing $\mathrm{CO}_{2}$ and convective processes leading to boundary layer growth (Culf et al., 1997). Local and global scales can be linked experimentally through a monitoring campaign of a certain region in spatial and temporal terms (Dolman et al., 2006; Gioli et al., 2004; Betts et al., 1992), preferably combined with model analyses using regional atmospheric transport models of high resolution (Perez-Landa et al., 2007a, b; Sarrat et al., 2007).

This paper will focus on modelling the regional carbon exchange of a certain region in an attempt to quantify $\mathrm{CO}_{2}$ fluxes from various sources at the surface. The following question will be addressed: What are the main controlling factors determining atmospheric carbon dioxide concentration at a regional scale as a consequence of the different surface fluxes?

To study this regional scale interaction it is important to use land surface descriptions of appropriate complexity, that include the main controlling mechanisms and capture the relevant dynamics of the system, and to represent the real-world spatial variability in soils and vegetation. In this study we use a fully, online coupled model, basically consisting of the Regional Atmospheric Modelling System (RAMS; Pielke et al., 1992; Cotton et al., 2003) coupled with a land surface scheme carrying carbon, heat and momentum fluxes (SWAPS-C, Soil Water Atmosphere Plant System-Carbon; Ashby, 1999; Hanan et al., 1998; Hanan, 2001). Area of interest is The Netherlands where in 2002 an intensive, two week measurement campaign was held, as part of the EUfinanced project RECAB ("Regional Assessment and monitoring of the CArbo Balance within Europe"). The ensuing database has been used to calibrate and validate the models used in the present study.

First, a description of the modelling system will be given, together with the various databases (e.g. anthropogenic emissions) that are incorporated in the atmospheric model and how some of these databases are downscaled in time and space. A short description of the measurement campaign will also be provided, detailing the various observations taken and followed by a summary of the synoptic weather during the campaign.

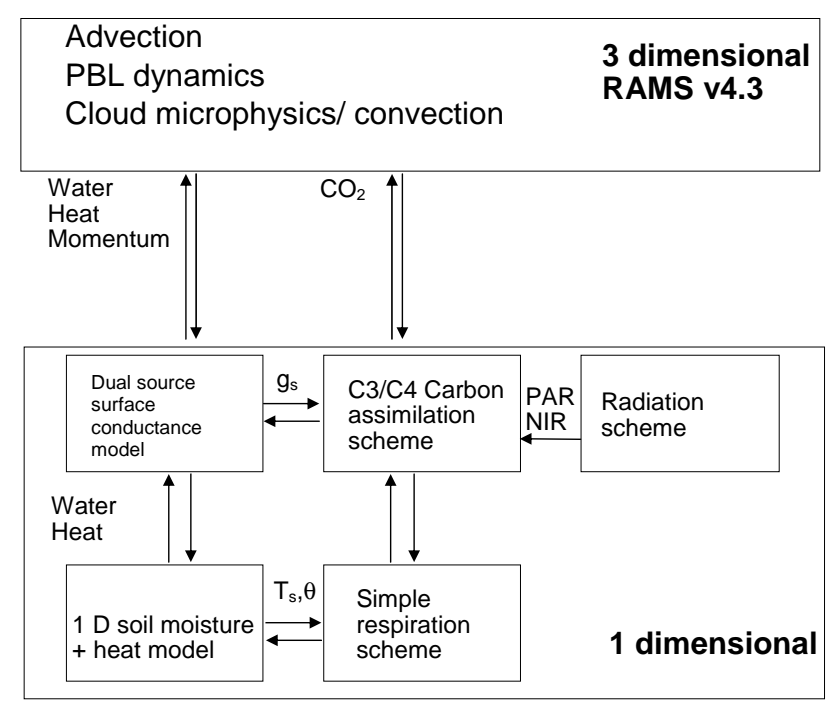

Fig. 1. Schematic of the coupling between RAMS and SWAPSC. The main interactions between submodels is also given together with the variables with $g_{\mathrm{S}}$ - surface conductance, $T_{\mathrm{S}}$ - surface temperature, $\theta$ - soil moisture, PAR - photosynthetically active radiation, NIR - near infrared radiation.

Next, the results of the coupled model will be presented and compared with the observations. This paper will conclude with a discussion of these results in terms of the factors that control the carbon dioxide content at a regional scale.

\section{Description of methods/observations}

\subsection{Modelling system}

The forward modelling system used in this study is the RAMS model version 4.3. The model is 3-D, nonhydrostatic, based on fundamental equations of fluid dynamics and includes a terrain following vertical coordinate system. Together with its nesting options these allow it to be used in high resolution modes. RAMS allows for passive atmospheric transport of any number of scalars and this has been implemented for $\mathrm{CO}_{2}$. Amongst other reasons we therefore coupled RAMS to SWAPS-C that simulates $\mathrm{CO}_{2}$ fluxes from assimilation and respiration. The land surface scheme uses the tile-approach for treating subgrid variability in vegetation and soils, in our implementation 4 tiles per grid box ( 1 water tile and 3 land tiles). The coupling has been implemented in such a way that both models retain full functionality (Fig. 1). The standalone version of SWAPS-C allows easy calibration of its parameters on measured flux datasets.

Surface layer turbulent mixing follows the standard formulation in RAMS and uses identical diffusion parameterisations for all three scalars (temperature, humidity and $\mathrm{CO}_{2}$ ). Unlike the other scalars, temperature and water vapour, atmospheric $\mathrm{CO}_{2}$ fields in this implementation are not nudged 
Table 1. RAMS4.3 configuration used in this study.

\begin{tabular}{llcl}
\hline Grids & 1 & 2 & 3 \\
\hline$d x, d y$ & $48 \mathrm{~km}(83 \times 83)$ & $16 \mathrm{~km}(41 \times 38)$ & $4 \mathrm{~km}(42 \times 42)$ \\
$d t$ & $50 \mathrm{~s}$ & $16.7 \mathrm{~s}$ & $16.7 \mathrm{~s}$ \\
$d z$ & \multicolumn{3}{c}{$25-1000 \mathrm{~m}(35)$} \\
Radiation & Harrington $(1997)$ \\
Topography & \multicolumn{2}{c}{ DEM USGS $(\sim 1 \mathrm{~km}$ resolution) } \\
Land cover & PELCOM (Mücher et al., 2001) \\
Land surface & \multicolumn{2}{c}{ SWAPS-C (Ashby, 1999; Hanan et al., 1998) } \\
Diffusion & Mellor/Yamada (Mellor and Yamada, 1982) \\
Convection & Full microphysics package (Flatau et al., 1989) \\
Forcing & \multicolumn{2}{c}{ ECMWF } \\
Nudging time scale & \multicolumn{2}{c}{ Lateral 1800 s } \\
\hline
\end{tabular}

to some pre-determined large scale analysis during long model integrations. Instead a different approach was followed using the interactive nesting routine in RAMS. The smallest domain has been nested in two larger domains and the atmospheric $\left[\mathrm{CO}_{2}\right]$ fields at the boundary are obtained from the parent grid (see Fig. 2). Thus, $\mathrm{CO}_{2}$ concentrations are free to develop, after the initial horizontal homogeneous initialisation from (aircraft) observed concentration profiles. We assume that the spatial differences in $\left[\mathrm{CO}_{2}\right]$ in the smallest domain, resulting from emissions and/or uptake at the surface, are larger than the spatial differences in background $\left[\mathrm{CO}_{2}\right]$ for the smallest domain. Higher $\left[\mathrm{CO}_{2}\right]$, as a result of $\mathrm{CO}_{2}$-emissions originating from cities outside the smallest domain (e.g. London and major cities in the Ruhr Area in Germany), will also be fed back into the smallest domain through the interactive nesting routine. Observations at the observatory in Mace Head at the west coast of Ireland demonstrate the small differences in background $\left[\mathrm{CO}_{2}\right]$ in relative clean air masses under northern hemispheric background conditions (Derwent et al., 2002). Since our analysis focuses on the smallest domain we assume that reasonable realistic horizontal gradients and associated advective fluxes develop along its edges, as a result of flux variability at the largest scales. The typical RAMS configuration used in this study is given in Table 1.

RAMS is forced by analysis data from the European Centre for Medium-Range Weather Forecasts (ECMWF) global model. The grid spacing of the forcing data is 0.5 by $0.5^{\circ}$ and data is available every $6 \mathrm{~h}$. Monthly sea surface temperatures (SST) have been extracted from the Met Office Hadley Centre's sea ice and sea surface temperature data set, HadISST1 (Rayner et al., 2003).

$\mathrm{CO}_{2}$ surface fluxes come from either of three sources:

- Terrestrial biospheric fluxes simulated by SWAPS-C

- Marine biospheric fluxes computed from large scale observed partial $\mathrm{CO}_{2}$ pressures in the marine surface layer

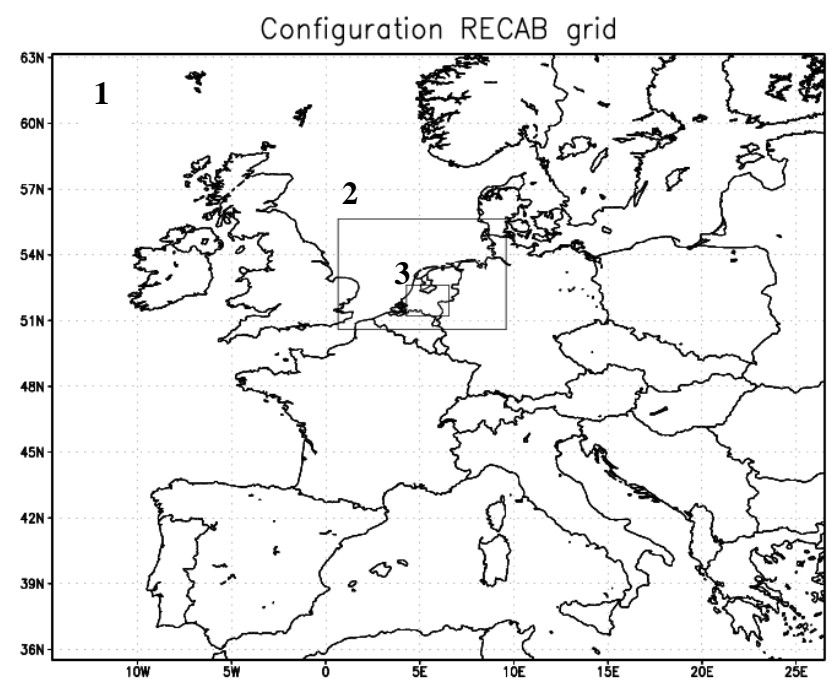

Fig. 2. Configuration of the modelling domain. Boxes and numbers illustrate the three nested grids.

\section{- Anthropogenic $\mathrm{CO}_{2}$ emissions}

Each of these will be described in the following sections.

\subsection{Terrestrial biospheric fluxes}

The land surface model SWAPS-C was extended with a carbon assimilation and respiration routine. The strength of SWAPS-C (Ashby, 1999), is that within the model aboveand below-ground processes are represented in similar physical details and that in earlier studies it has been shown that the model simulates energy fluxes and long-term soil moisture (Kabat et al., 1997) very well. The model allows for three different canopy architectures with a mean canopy flow regulating interaction of fluxes from upper and lower layers (Dolman, 1993). Photosynthesis and respiration are parameterised using the equations used by Collatz et al. (1992), 
Table 2. Parameters for calculating the surface conductance and the net ecosystem exchange, classified by land use. $g_{\mathrm{s}, \text { max }}$ : maximum surface conductance $\left(\mathrm{mm} \mathrm{s}^{-1}\right), V_{\mathrm{m} \text {,ref: }}$ maximum catalytic capacity for Rubisco at canopy level $\left(\mu \mathrm{mol} \mathrm{m} \mathrm{s}^{-2} \mathrm{~s}^{-1}\right)$ and $\alpha$ the intrinsic quantum use efficiency $[-]$.

\begin{tabular}{|c|c|c|c|c|}
\hline & $\begin{array}{c}g_{\mathrm{s}, \max } \\
\left(\mathrm{mm} \mathrm{s}^{-1}\right)\end{array}$ & $\begin{array}{l}V_{\mathrm{m}, \mathrm{ref}} \\
\left(\mu \mathrm{mol} \mathrm{m}{ }^{-2} \mathrm{~s}^{-1}\right)\end{array}$ & $\begin{array}{c}\alpha \\
(-)\end{array}$ & \\
\hline $\begin{array}{l}\text { Coniferous } \\
\text { forest }\end{array}$ & 33.4 & 55.8 & 0.0384 & Optimized \\
\hline $\begin{array}{l}\text { Deciduous } \\
\text { forest }\end{array}$ & 51.0 & 41.0 & 0.0084 & $\begin{array}{l}\text { Ogink-Hendriks (1995), } \\
\text { Knorr (2000) }\end{array}$ \\
\hline Grass & 25.9 & 91.96 & 0.0283 & Optimized \\
\hline $\begin{array}{l}\text { Agricultural } \\
\text { land }\end{array}$ & 25.0 & 39.0 & 0.0475 & $\begin{array}{l}\text { Soet et al. (2000), } \\
\text { Knorr (2000) }\end{array}$ \\
\hline
\end{tabular}

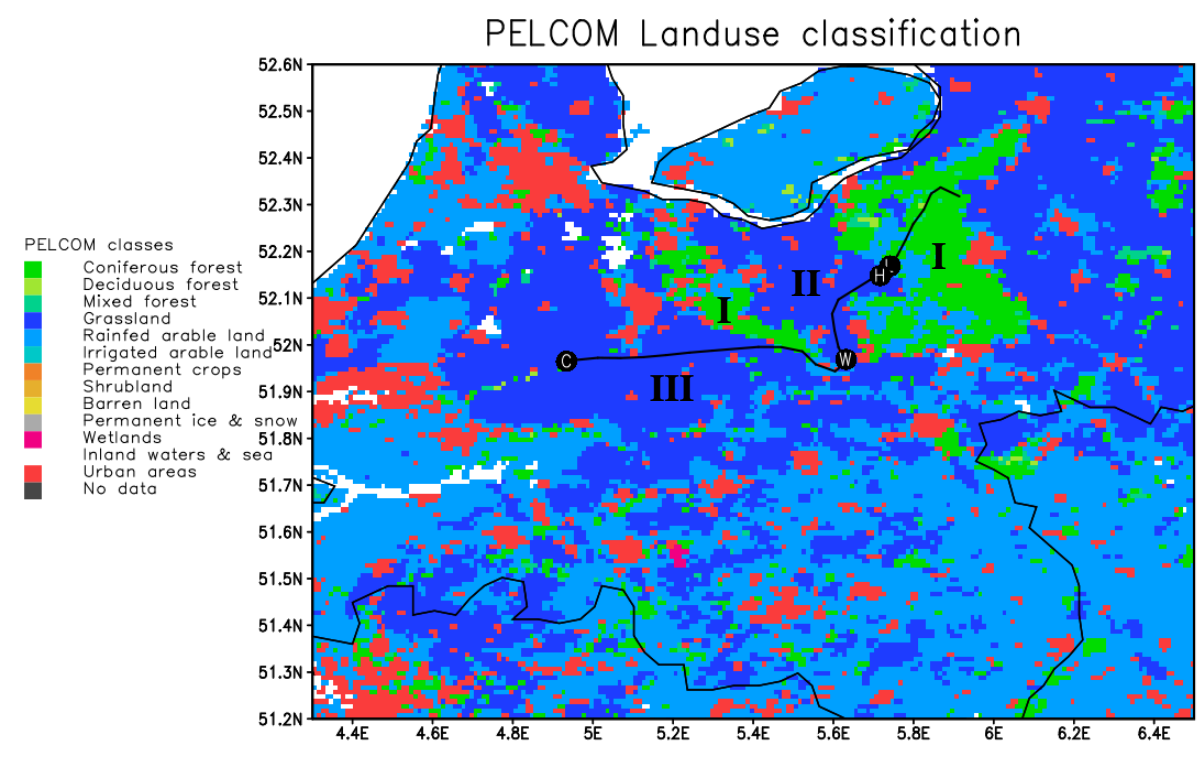

Fig. 3. Land cover classification (based on PELCOM) for the smallest grid in the domain. Along the flight track (black line) the location of the observational sites are also given: $\mathrm{C}$ - Cabauw; W - Wageningen; $\mathrm{H}$ - Harskamp; L - Loobos. The roman numbers correspond to the areas described in the text.

Hanan et al. (1998) and Lloyd et al. (1995). Although these equations were originally developed for leaf scale, in SWAPS-C they are applied at canopy scale assuming the canopy can be described as a "big leaf". Model parameters for each land use class were either objectively optimized against observed flux data (coniferous forest, grasslands) or taken from literature (deciduous forest and croplands, from e.g. Ogink-Hendriks, 1995; Spieksma et al., 1997; Van Wijk et al., 2000; Soet et al., 2000; Knorr, 2000; see Table 2). The parameters were optimized by minimizing the sum of squares of differences between model predictions and measurements using a Marquardt-Levenberg algorithm for optimization (Marquardt, 1963).

The land use map used in the model is extracted from the $1 \mathrm{~km}$ resolution PELCOM database (Mücher et al., 2001; Fig. 3). Soil properties were derived from the IGBP-DIS Soil
Properties database (Global Soil Data Task Group, 2000) that has a resolution of approximately $10 \mathrm{~km}$ (Fig. 4). In RAMS overlays are generated using vegetation and soil maps and then for each grid box the most frequently occurring soilvegetation combinations are determined, which are then assigned to the number of sub-grid tiles effective in that particular implementation.

\subsection{Marine biospheric fluxes}

The exchange of carbon between ocean and atmosphere has been based on the global compilation of the partial pressure of $\mathrm{CO}_{2}\left(p \mathrm{CO}_{2}\right)$ by Takahashi et al. (1997). The reference year of this climatological database is 1990 and its resolution is 5 by $4^{\circ}$ on a monthly basis (see Fig. 5). The prominent peak in October is in line with the findings of 


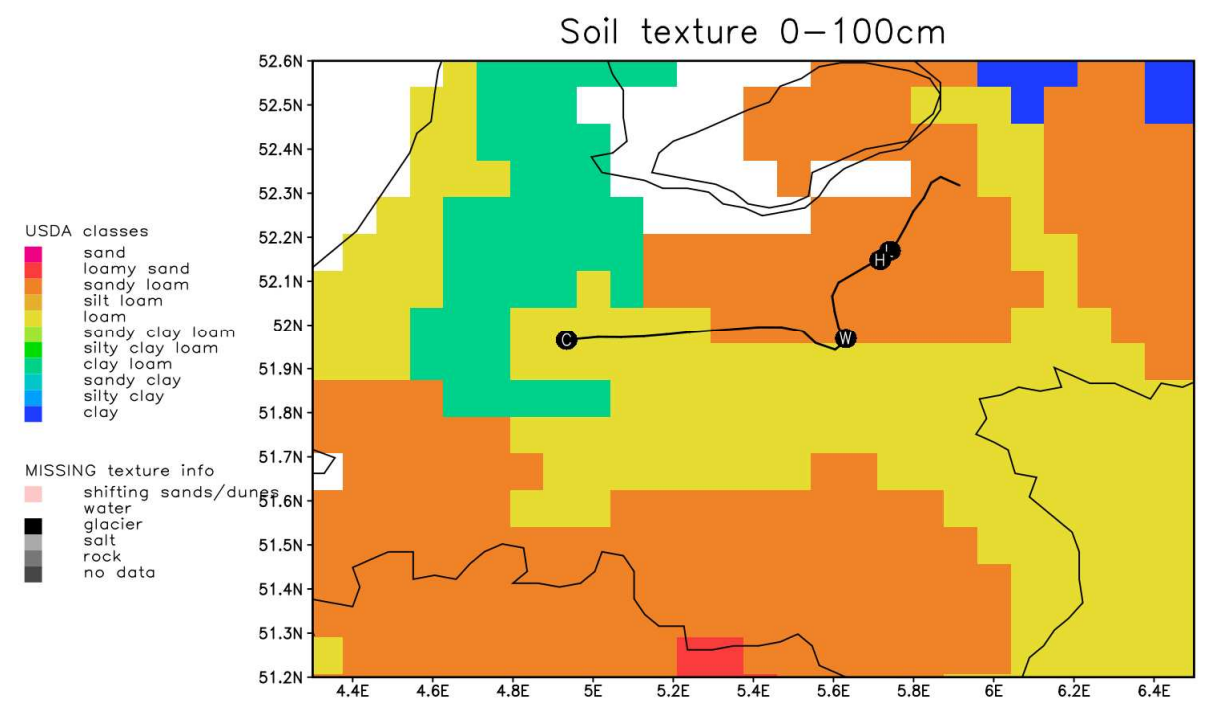

Fig. 4. Soil classification (depth $0-100 \mathrm{~cm}$ ) for the smallest grid in the domain. Along the flight track (given as a black line) the location of the observational sites are also given: $\mathrm{C}$ - Cabauw; $\mathrm{W}$ - Wageningen; $\mathrm{H}$ - Harskamp; L - Loobos.
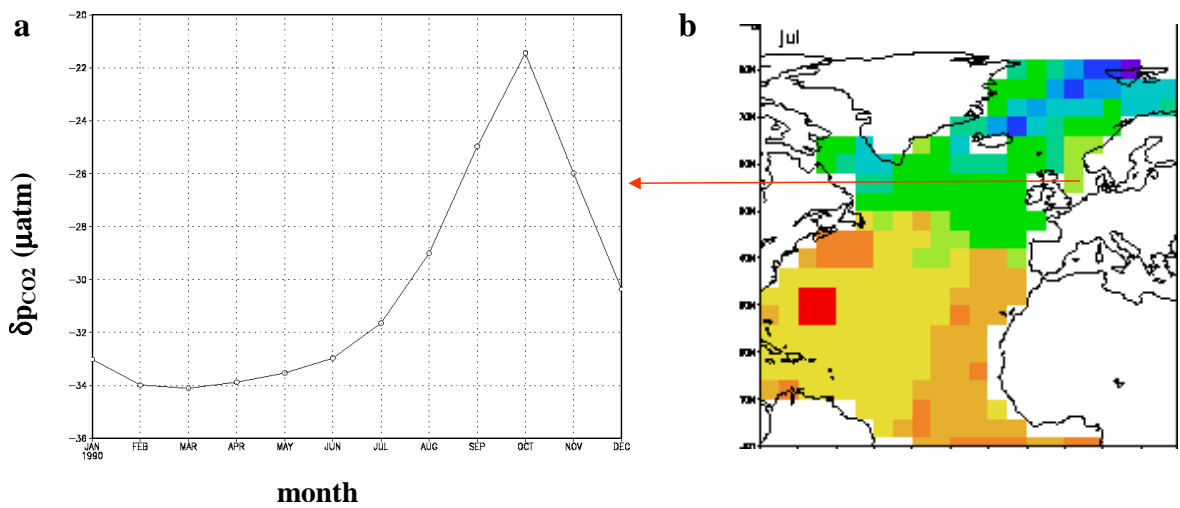

Fig. 5. (a) Monthly dynamics of $\delta p \mathrm{CO}_{2}(\mu \mathrm{atm} ; 1 \mathrm{~atm}=1.01325 \mathrm{~Pa})$ as a time series for a pixel in the North Sea (left panel), (b) Spatial representation of $\delta p \mathrm{CO}_{2}$ for the Atlantic Ocean.

Hoppema (1991), who attributed this peak mainly to mixing of fresh water and saline North Sea water. From this seasonally varying partial pressure we derive the $\mathrm{CO}_{2}$-flux depending also on (simulated) wind speed and to a lesser degree on SST following Wanninkhof (1992) and Weiss (1974). To prevent unrealistic sharp flux jumps at resolutions higher than the original 5 by $4^{\circ}$, we downscaled the dataset to $1^{\circ}$ resolution by simple linear interpolation.

\subsection{Anthropogenic $\mathrm{CO}_{2}$ emissions}

Anthropogenic emissions from road transport, power generation and air traffic are important $\mathrm{CO}_{2}$ sources in our domain. The emission inventory implemented in the RAMS/SWAPSmodelling system is the EDGAR 3.2 database (Olivier and Berdowski, 2001). The spatial resolution of this database is $1^{\circ}$ and annual emissions of $\mathrm{CO}_{2}$ are available for 1995 (see
Fig. 6). Emissions over the oceans from shipping and upperair emissions from air traffic are neglected in this process.

To get a better spatial representation of anthropogenic emissions, these emissions are downscaled in space. This is done by equally distributing the emissions of a particular 1 by 160 grid box over all the 1 by $1 \mathrm{~km}$ urban pixels in the land cover map. Mismatches due to differing land-sea masks at different resolutions have been solved by distributing the emission of an EDGAR pixel found over sea over its neighbouring land pixels following knowledge of the local situation.

The emissions are also disaggregated in time and here a distinction is made between the "mobile" emissions (mostly road transport) and non-mobile emissions (industry, energy and small combustion and residential). For mobile emissions a diurnal cycle is assumed with no seasonal cycle where as for the non-mobile emissions a seasonal cycle is assumed 
$\mathbf{a}$

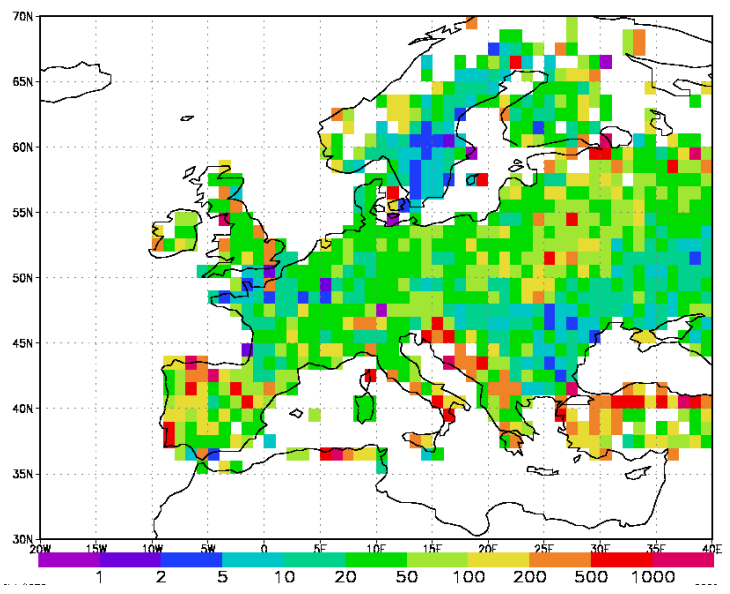

b
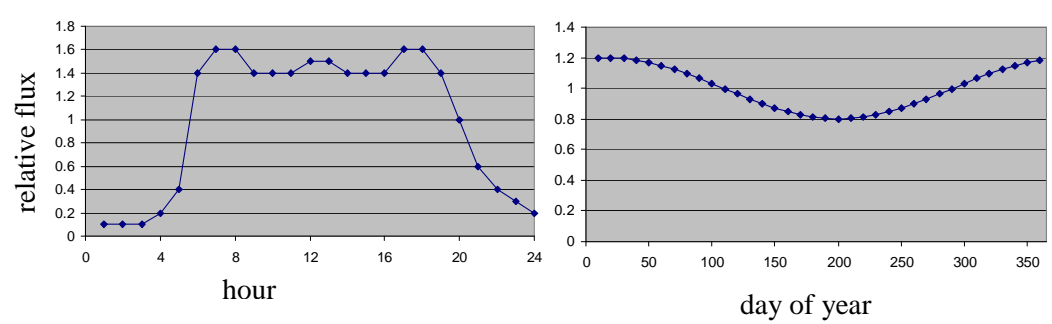

Fig. 6. (a) Anthropogenic $\mathrm{CO}_{2}$ flux (terrestrial only) in $\mu \mathrm{mol} \mathrm{m}{ }^{-2} \mathrm{~s}^{-1}$ from EDGAR database version 3.2, (b) Temporal disaggregation of these emissions: mobile emissions (left) vary diurnally, non-mobile emissions (right) vary seasonally. Note that the emission is per $\mathrm{m}^{2}$ urban area per pixel.

with no diurnal cycle. Both graphs in Fig. 6 show the relative contribution of that category to the emission. In the mobile emissions clearly a higher emission value can be seen during rush hours in the morning and evenings and almost no emission during night time. The shape of this graph is based upon work done by Wickert (2001) and Kuhlwein et al. (2002). For the non-mobile emissions a different pattern can be seen with higher emissions for Europe during wintertime as a result of higher heating rates.

\subsection{Region}

The simulations are performed for the RECAB summer campaign which was held between 8 and 28 July 2002. The experimental region comprises a big part of the centre of The Netherlands, measuring $70 \mathrm{~km}$ diagonally between the flux tower of Loobos and the tall tower of Cabauw. Figures 3 and 4 both show the location of both towers together with other observational sites (Haarweg-site in Wageningen and Harskamp) which were used during the campaign. These figures also show the land use cover and the soil map of the area. On these maps four major landscape units can be distinguished (Roman numbers on Fig. 3):

- hilly glacial deposits of coarse texture mainly covered by various forest types (evergreen needle leaf, deciduous broadleaf and mixed); maximum altitude $110 \mathrm{~m}$ a.m.s.l. (above mean sea level) (area I)

- agricultural land dominated by a mixture of grassland and maize crops on mostly sandy soils in between the hilly glacial deposits (area II)

- very low lying, wet grassland on clay and/or peat soils, mostly along the major rivers to the south of the line Wageningen - Cabauw (area III)

- urban areas (bright red areas in Fig. 3)

The region has a maritime temperate climate. During the campaign the local weather was rather unstable, cloudy and slightly colder and wetter than average. The maximum temperature dropped to values well below $20^{\circ} \mathrm{C}$ at three days in the campaign and only in the final days of the campaign the temperature started to rise strongly to maximum values of $25-30^{\circ} \mathrm{C}$. The prolonged period of cold weather was accompanied with cloudy circumstances from time to time, leading to precipitation. At Loobos a total of $14.2 \mathrm{~mm}$ was measured during this period. During this colder period it was impossible for the aircrafts to do proper measurements and therefore flying days were limited to the starting days and ending days of the campaign. 
Table 3. Description of observational sites during the RECAB campaign.

\begin{tabular}{llll}
\hline Site & Location & Landuse & \\
\hline Loobos & $\begin{array}{l}5.7439 \mathrm{E}, \\
52.1667 \mathrm{~N}\end{array}$ & Coniferous forest & $\begin{array}{l}\text { Fluxes of } \mathrm{H}, \mathrm{LE} \\
\text { and } \mathrm{CO}_{2}, \text { weather }\end{array}$ \\
$\begin{array}{l}\text { Harskamp } \\
\text { (mobile) }\end{array}$ & $\begin{array}{l}5.7157 \mathrm{E}, \\
52.1491 \mathrm{~N}\end{array}$ & $\begin{array}{l}\text { Maize (Agricultural } \\
\text { land) }\end{array}$ & $\begin{array}{l}\text { Fluxes of } \mathrm{H}, \mathrm{LE} \\
\text { and } \mathrm{CO}_{2}, \text { weather }\end{array}$ \\
Wageningen & $5.628 \mathrm{E}, 51.977 \mathrm{~N}$ & Grassland & $\begin{array}{l}\text { Fluxes of } \mathrm{H}, \mathrm{LE} \\
\text { and } \mathrm{CO}_{2}, \text { weather }\end{array}$ \\
& $4.927 \mathrm{E}, 51.971 \mathrm{~N}$ & Grassland & $\begin{array}{l}\text { Fluxes of } \mathrm{H}, \mathrm{LE} \\
\text { and } \mathrm{CO}_{2}, \text { weather, } \\
\text { concentrations of } \\
\mathrm{CO}_{2} \text { and othet GHGs }\end{array}$ \\
& & &
\end{tabular}

\subsection{Observations}

Campaignwise observations have been made of:

- fluxes of $\mathrm{CO}_{2}$ between land and atmosphere deploying permanent (3) and mobile (1) eddy-correlation flux towers (see Table 3).

- aircraft fluxes of momentum, latent and sensible heat, and $\mathrm{CO}_{2}$ performed with the eddy covariance technique, using a low-flying aircraft (Sky Arrow ERA). Flight altitude was $80 \mathrm{~m}$ a.g.l. (above ground level). The methodology and the validation of such measurements against flux towers can be found in Gioli et al. (2004).

- convective boundary layer (CBL) concentrations of $\mathrm{CO}_{2}$ and other greenhouse gases, deploying flask-and continuous sampling from an aircraft (Piper Cherokee), and continuous sampling from the tall tower at Cabauw.

\subsection{Aircraft fluxes uncertainty estimation}

Aircraft eddy fluxes typically show a high variability, that is related to random flux errors like those induced by large convective structures, spatial heterogeneity, and transient processes like mesoscale motions. To estimate such contributions to observed variability and derive uncertainty figures, multiple passes over the same area in stationary conditions can be used (Mahrt et al., 2001), but such an approach is possible only for small areas that can be adequately sampled in short amount of time. The experimental strategy used in RECAB was instead to fly and sample large areas comparable to regional model domains, with a small number of repetitions.

To partially overcome this limitation in characterizing uncertainty, fluxes have been computed on a $2 \mathrm{~km}$ spatial length, then groups of four consecutive windows over homogeneous landscape units have been averaged to derive $8 \mathrm{~km}$ fluxes, that are still comparable with model resolution. The standard deviation of such averaging process is related to random flux errors, surface heterogeneity within the $8 \mathrm{~km}$ length, and non stationarity of fluxes on larger time scales. This latter effect can generally be ruled out because of the short amount of time that separates the averaged $2 \mathrm{~km}$ windows, up to few minutes. Thus an uncertainty estimation, mostly related to random flux error and surface heterogeneity, is derived and used to interpret the observations.

Flying days during the campaign were on 15, 16, 23, 24, 25,26 and 27 July with the last day in the best meteorological conditions. On 15, 16, 24 and 27 July two return flights from Loobos to Cabauw were performed with the low-flying eddycorrelation flux aircraft and on 15, 16 and 27 July vertical profiles were taken in the morning and in the afternoon with the aircraft performing CBL measurements. This paper will focus on the first period of the summer campaign as for these days multiple reliable observations are available to test the model.

\section{Results and analyses}

The results of the model have been compared to observations carried out during the RECAB summer campaign. First, a comparison will be made between station observations and simulated results focussing on the various fluxes between the land surface and atmosphere. Second, the observations carried out by the aircrafts are compared with model results. These will be divided into comparisons of vertical profiles of $\mathrm{CO}_{2}$ concentrations and temperatures on one hand and comparisons of latent heat, sensible heat and $\mathrm{CO}_{2}$-fluxes along paths flown by the low-flying flux aircraft on the other. Model output is stored every hour and only output from the smallest $4 \mathrm{~km}$ grid resolution is presented. For comparison with the observational tower data, model output was taken from the grid point nearest to the observational site. Aircraft data was compared against interpolated model output using bilinear interpolation in a horizontal rectangular grid in space followed by a linear interpolation in time. 
(a)

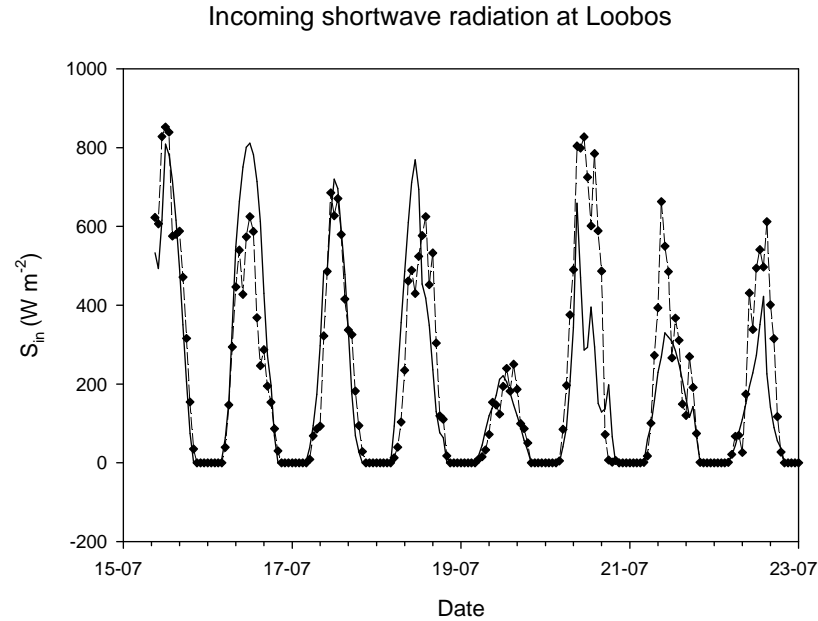

(b)

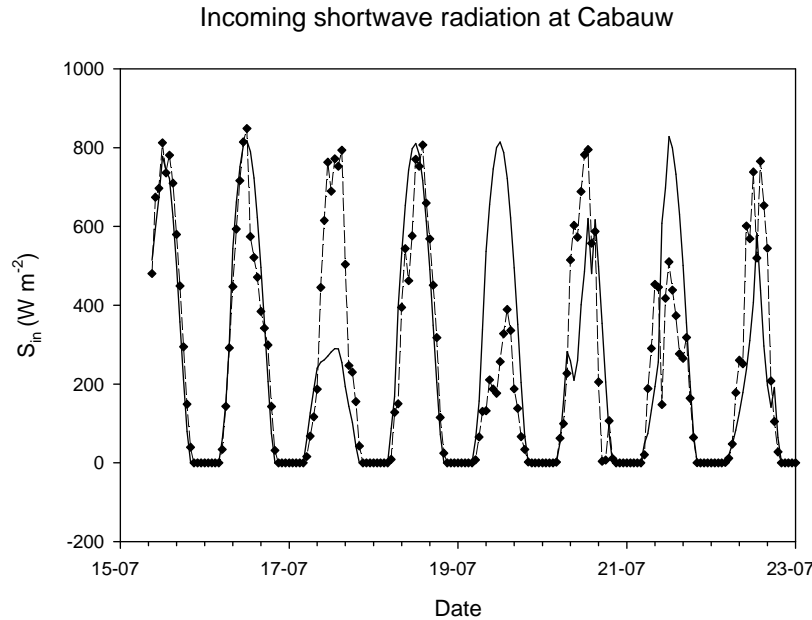

Fig. 7. Comparison of observed and simulated incoming shortwave radiation fluxes $\left(\mathrm{W} \mathrm{m}^{-2}\right)$ at the Loobos and Cabauw sites. Diamonds and dotted lines: observed values. Black lines simulated at a grid point nearest to the Loobos site and representing the appropriate tile. Tick marks are placed at 00:00 h, same for Figs. 8, 9 and 14 .

\subsection{Validation against station observations}

In the first set of graphs we compare simulated fluxes at grid and patch level with observed fluxes at the tower sites. Each grid box of a model can represent more than one land use class in the so-called tile-approach for sub-grid variability. We compare fluxes for the grid box nearest to the towersite, and for the land cover class most resembling the land cover at the tower site. For the grid cell including the Loobos pine forest site we find the following distribution of land use classes $44 \%$ forest, $44 \%$ grassland and $11 \%$ agriculture. The same grid cell also covers the nearby Harskamp maize site. The grid cell containing the Cabauw grass site contains $100 \%$ grassland. The Wageningen (grassland in reality) grid
Table 4. Statistical analysis of simulated against observed shortwave incoming radiation $\left(\mathrm{W} \mathrm{m}^{-2}\right)$, latent heat flux $\left(\mathrm{W} \mathrm{m}^{-2}\right)$ and net ecosystem exchange $\left(\mu \mathrm{mol} \mathrm{m} \mathrm{m}^{-2} \mathrm{~s}^{-1}\right)$. These statistics are based on hourly observations and simulated results for the period 15 July 2002-29 July 2002.

\begin{tabular}{lrcc}
\hline \multicolumn{5}{c}{ Incoming shortwave radiation } \\
\hline Site & RMSE & Slope & $r^{2}$ (correlation coeff.) \\
Loobos & 138.492 & 0.792 & 0.708 \\
Cabauw & 187.443 & 0.778 & 0.591 \\
Wageningen & 158.728 & 0.739 & 0.621 \\
\hline \multicolumn{4}{c}{ Latent heat flux } \\
\hline Site & RMSE & Slope & $r^{2}$ \\
Loobos & 53.693 & 0.704 & 0.578 \\
Cabauw & 56.783 & 0.618 & 0.485 \\
Wageningen & 78.536 & 0.470 & 0.584 \\
Harskamp & 64.053 & 0.821 & 0.693 \\
\hline \multicolumn{4}{c}{ Net ecosystem exchange } \\
\hline Site & RMSE & Slope & $r^{2}$ \\
Loobos & 5.249 & 0.583 & 0.648 \\
Cabauw & 4.515 & 0.530 & 0.707 \\
Wageningen & 5.070 & 0.452 & 0.702 \\
\hline
\end{tabular}

cell contains $56 \%$ grassland, $33 \%$ agriculture and $11 \%$ urban area.

Figure 7 shows a comparison of observed and simulated incoming shortwave radiation $\left(\mathrm{W} \mathrm{m}^{-2}\right)$ for the Loobos and Cabauw sites, statistics are given in Table 4. For a number of days the agreement is very good at both sites, but for other days the model underestimates the global radiation. This is mostly due to a misrepresentation of the exact location and timing of the passage of various simulated cloud systems. As mentioned before the local weather was rather unstable. For example, the second day in the simulation (16 July) was a day with clear conditions in most of The Netherlands except for the eastern part. This is reflected in the observations at Loobos compared to the observed incoming shortwave radiation at Cabauw. However, the model simulates clear conditions not only for the western part but also for the eastern part of The Netherlands with cloudy conditions simulated approximately $50 \mathrm{~km}$ east of Loobos site. Comparisons with other sites show similar results. Overall the incoming shortwave radiation is underestimated by $20-25 \%$ at Loobos, Cabauw and Wageningen with a correlation coefficient $\left(r^{2}\right)$ varying between 0.591 and 0.708 (Table 4).

Since largely determined by available solar energy, similar patterns can be found in the comparison between observations and model for the latent heat flux $\left(\mathrm{W} \mathrm{m}^{-2}\right)$. Figure 8 shows the observed and simulated latent heat flux for the three main land use types: needle leaf forest (Loobos), grassland (Wageningen) and agricultural land (Harskamp). 
(a)

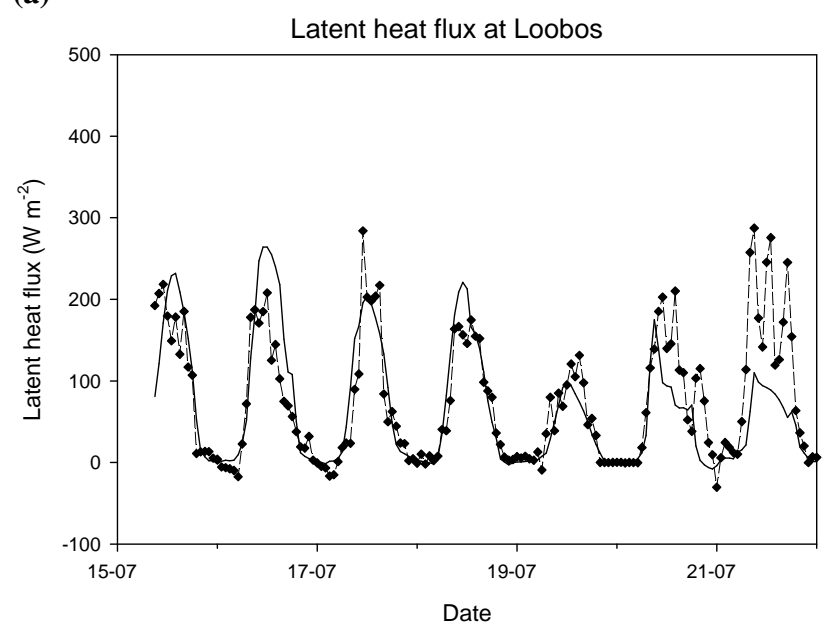

(b)

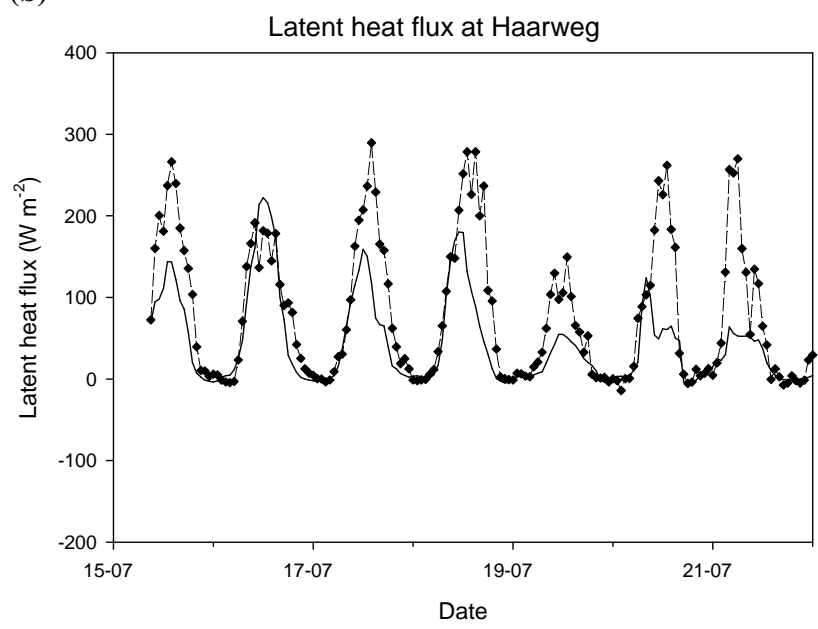

(c)

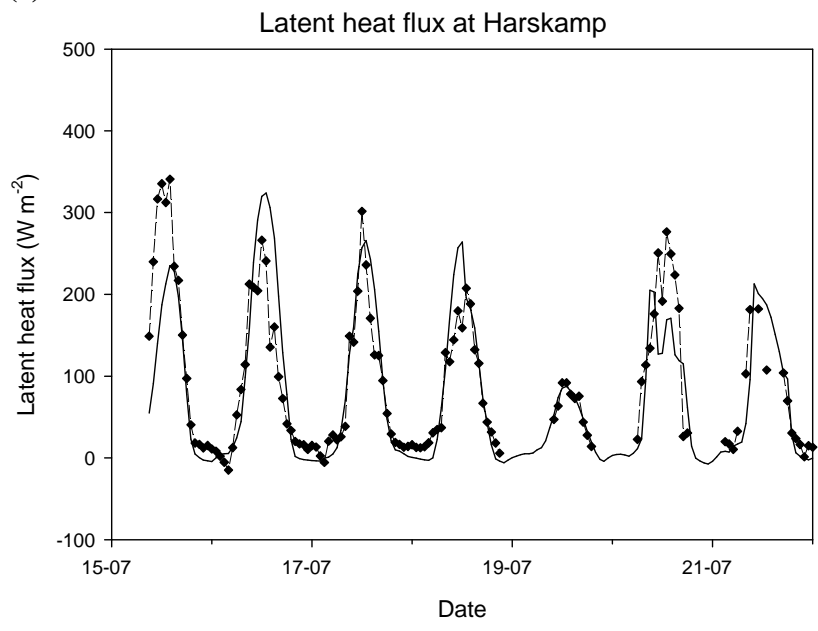

Fig. 8. Comparison of observed and simulated latent heat fluxes $\left(\mathrm{W} \mathrm{m}^{-2}\right)$ for Loobos - (a) forest site - Wageningen - (b) grass site - and Harskamp - (c) maize site. Diamonds and dotted lines: observed values; black lines simulated at a gridpoint nearest to the observational site and representing the appropriate tile. (a)

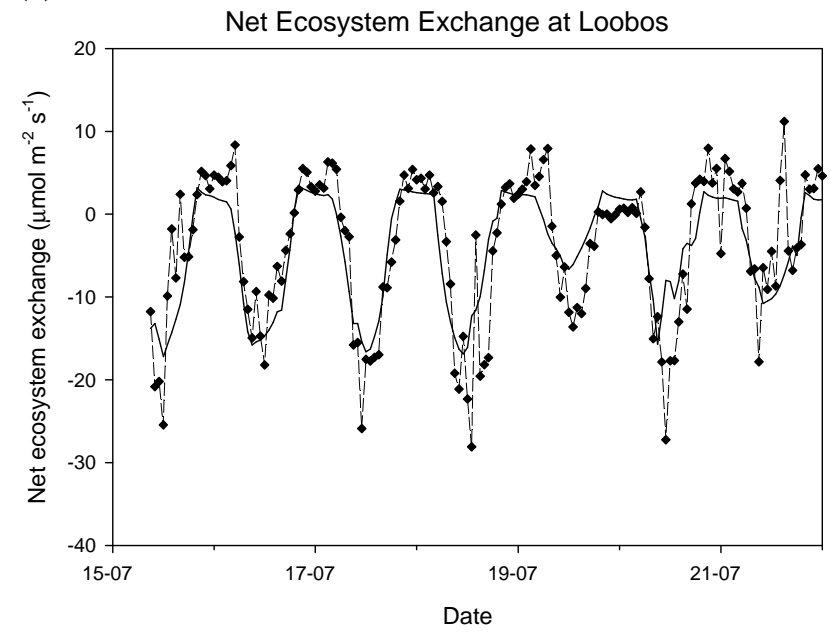

(b)

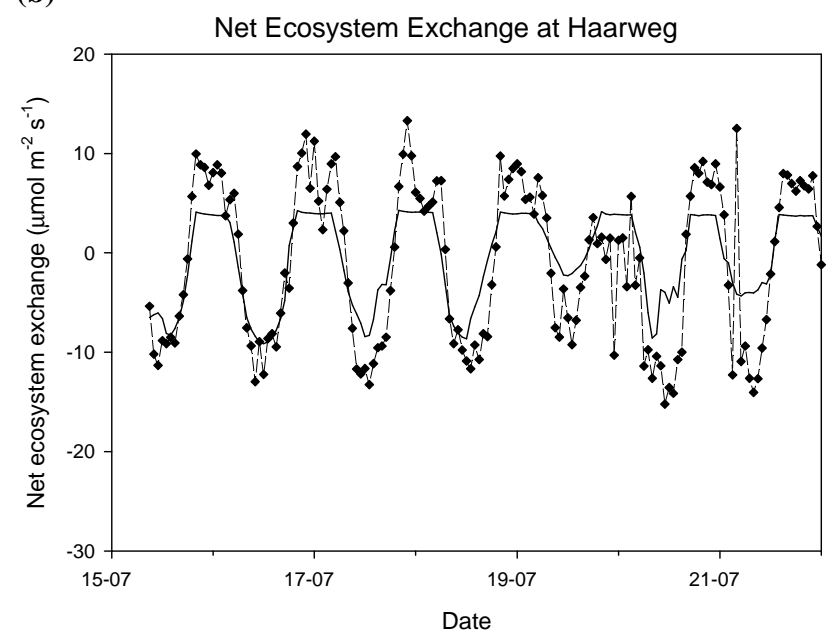

Fig. 9. Comparison of observed and simulated $\mathrm{CO}_{2}$ fluxes $\left(\mu \mathrm{mol} \mathrm{m}{ }^{-2} \mathrm{~s}^{-1}\right.$ ) for Loobos (a) and Wageningen (b). Diamonds and dotted lines: observed values; black lines simulated at a gridpoint nearest to the observational site and representing the appropriate tile.

In general, evaporation is underestimated by $20-35 \%$, much like shortwave radiation. Only for the Wageningen grassland site the evaporation is underestimated by twice as much as the driving radiation is.

Simulated $\mathrm{CO}_{2}$ fluxes $\left(\mu \mathrm{mol} \mathrm{m} \mathrm{m}^{-2} \mathrm{~s}^{-1}\right.$ ) are compared with observations in Fig. 9. Only the Loobos and Wageningen sites are displayed here, as the $\mathrm{CO}_{2}$ observations of the Harskamp site were limited in this period due to problems with the measurement instrument. However, for this site from the few data available we can conclude that the simulated $\mathrm{CO}_{2}$ uptake of the maize is underestimated as a result of the generic parameter values obtained from literature (Knorr, 2000). This lack of observational data made it impossible to derive correct parameter values for the maize-site in 
Table 5. Landscape averaged latent heat fluxes $\left(\mathrm{W} \mathrm{m}^{-2}\right)$ along the flightpath for both flights on 16 July 2002. The three landscapes (see text) are referred to according to their roman number in Fig. 3. flux atm represents the simulated flux at the same level as the flightpath, whereas flux sfc represents the simulated flux at the land surface below the flightpath.

\begin{tabular}{lrrrr}
\hline 16/07 1st flight & I & II & III & entire flightpath \\
\hline average observation & 141.7 & 140.7 & 179.1 & 163.3 \\
average flux atm & 43.4 & 14.0 & 1.5 & 12.4 \\
average flux sfc & 73.7 & 60.6 & 53.6 & 59.5 \\
\hline 16/07 2nd flight & I & II & III & entire flightpath \\
\hline average observation & 185.4 & 199.6 & 243.4 & 219.0 \\
average flux atm & 155.6 & 173.3 & 181.9 & 174.8 \\
average flux sfc & 249.6 & 216.1 & 217.9 & 223.2 \\
\hline
\end{tabular}

Harskamp. Another complication is that PELCOM does not discriminate between specific crops in the PELCOM classes of rain fed or irrigated arable land (see Fig. 3). The simulated net ecosystem exchange (NEE; $\mu \mathrm{mol} \mathrm{m}{ }^{-2} \mathrm{~s}^{-1}$ ) is simulated well for Loobos and to a lesser degree for Wageningen. At Loobos, except for some unexplained midday peaks, the simulated assimilation is quantitatively in accordance with the observations. At 19 and 20 July assimilation is underestimated by the model. During these days the model simulates for both sites a weaker photosynthesis than the observations show. Especially, 19 July is characterized by a shortwave radiation which is limited by cloud cover in both simulations and observations (see Fig. 7). The effect of reduced shortwave radiation on the $\mathrm{CO}_{2}$ flux appears stronger in the model than in the observations. The daytime NEE at Wageningen is on average underestimated by $2-3 \mu \mathrm{mol} \mathrm{m}{ }^{-2} \mathrm{~s}^{-1}$ which is a result of an underestimation of incoming shortwave radiation by the model. Due to simulated clouds, the model simulates incoming shortwave radiation values which are 100$400 \mathrm{~W} \mathrm{~m}^{-2}$ lower than the observations. At the grass-sites of Wageningen and Cabauw (another grass site, not shown), the model has clearly difficulties in simulating night time respiration, but for the forest site the respiration is simulated better. The simulated respiration at Loobos is of the same order of magnitude although the model has difficulty in simulating the apparent morning respiration peak at 16 July and 19 July. Statistics displayed in Table 4 show that overall the absolute NEE is underestimated at Wageningen by more than $50 \%$ which is largely explained by a structural underestimation of especially respiration.

\subsection{Validation against aircraft observations}

Figures 10 and 12 respectively show spatially explicit simulated latent heat and carbon fluxes in comparison with those observed from the flux aircraft, for 16 July around 07:00 a.m. UTC and 11:00 a.m. UTC (09:00 a.m. and 01:00 p.m. LT - local time). The top panel of both figures show the spatial patterns of the simulated fluxes combined with an overlay of the flight track. The lower panel shows a comparison between simulated and observed fluxes in terms of both their absolute values and anomalies of the flux, defined as the deviation from the average of the total flight track. These are also normalized by the standard deviation of the data points

$F^{\prime}=\frac{F-\bar{F}}{\sigma}$

Figures 10 and 12 demonstrate that the wind direction and speed (displayed as wind vectors) are simulated in accordance with the observations from the aircraft. Comparing spatially explicit simulated and observed fluxes shows that in general simulated latent heat fluxes are lower than observed (Fig. 10). Table 5 presents the average latent heat flux per major landscape unit (I, II and III in Fig. 3) for both flights on 16 July. The difference between observed and simulated fluxes for all landscape units is notably larger for the early morning flight on 16 July with fluxes underestimated on average for the whole flight track by almost $150 \mathrm{~W} \mathrm{~m}^{-2}$. If the uncertainty is taken into account, this underestimation is reduced. However, the fact remains that the simulated flux at flight level is near zero due to a lack of turbulent diffusion. This is probably a result of a stable boundary layer in the early morning which is simulated too shallow. The discrepancy in latent heat flux between model and airplane is not in line with the validation on station level (see Fig. 8) where latent heat flux is reasonably simulated by the model on 16 July. The average simulated latent heat flux for the second flight on 16 July is more in line with observation with a simulated latent heat flux of $174.8 \mathrm{~W} \mathrm{~m}^{-2}$ compared to an observed flux of $219.0 \mathrm{~W} \mathrm{~m}^{-2}$. This underestimation is detected in all landscape units but is most apparent for landscape unit III (wet grassland along the river). We can also see that simulated flux divergence with height can be considerable (green and blue lines in the Fig. 10, flux atm vs. flux sfc in the Table 5). For the second flight observed values fall in between the flux magnitudes simulated at the surface and at flight altitude. However, uncertainty in observed latent heat fluxes is very large (average uncertainty of $110 \mathrm{~W} \mathrm{~m}^{-2}$ for first flight; $137 \mathrm{~W} \mathrm{~m}^{-2}$ for second flight) making it almost impossible to draw firm conclusions. This is true especially for the afternoon flight of 16 July, where high variability in incoming radiation is also present, possibly inducing non stationary conditions even within the relatively small averaging lengths, and holds for other latent heat flux observations of aircraft measurements during the observational campaign. 
(a)
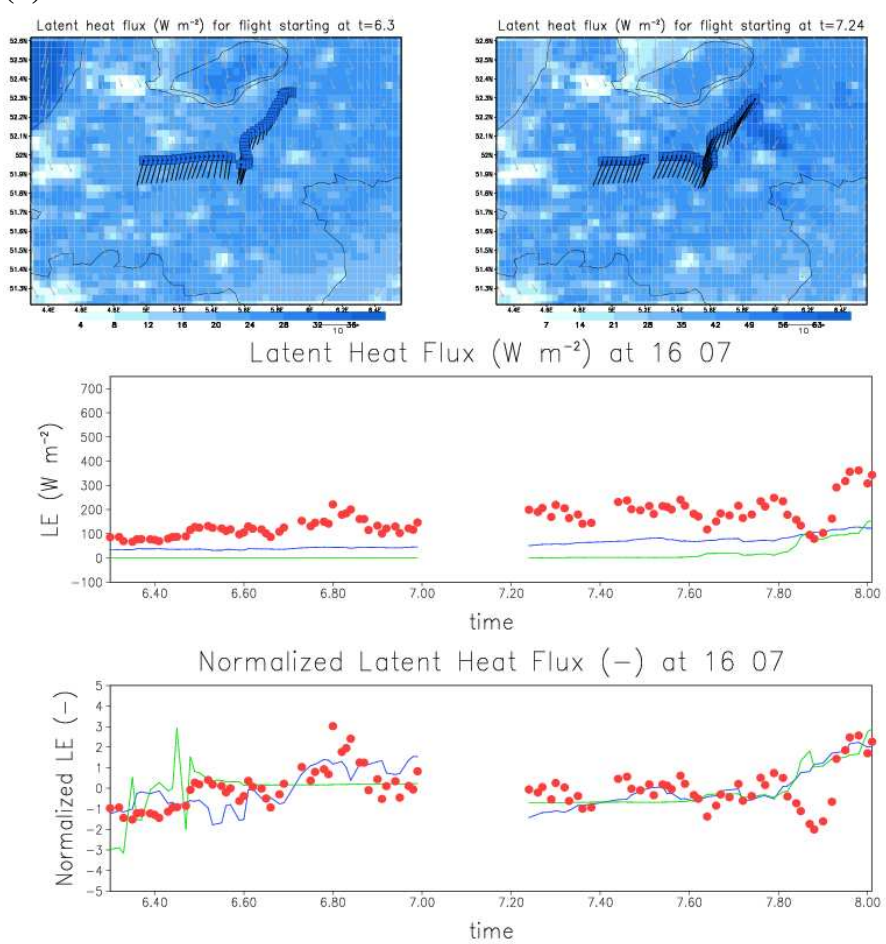

(b)
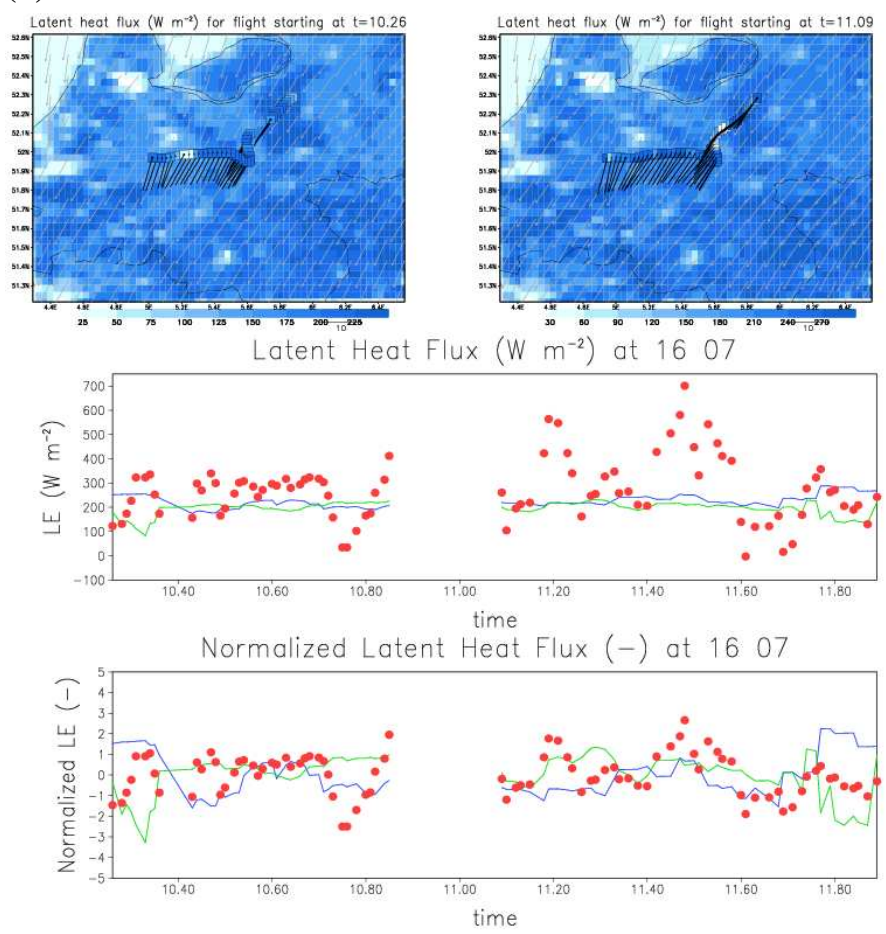

Fig. 10. Spatial comparison of latent heat fluxes $\left(\mathrm{W} \mathrm{m}^{-2}\right)$ against aircraft observations, for the flights on 16 July $2002-(\mathbf{a})$ : $06.28 \mathrm{UTC}$, 07.22 UTC; (b): 10:25 UTC, 11:07 UTC. The maps show simulated latent heat flux at the surface and wind vectors (gray). Superimposed on that is the flight track with observed fluxes (squares) in the same colour coding as the background map, plus aircraft observed windvectors (black). The lower plots in (a) and (b). show the aircraft observed fluxes (red dots), simulated fluxes at the surface (dark blue) and at flying altitude (green) in terms of both their absolute values and anomalies of the flux which is defined as the deviation from the average of the total flight track divided by the standard deviation. Simulated fluxes have been interpolated from model grid to exact location and time of flight overpass. The early flight moves from NE to SW, the return flight from SW to NE. So in the scatter plot the left side is the NE the middle the SW and the right side NE again. 
(a)

Airborne observations of Latent Heat Flux $\left(\mathrm{W} \mathrm{m}^{-2}\right)$ at 16 July 2002

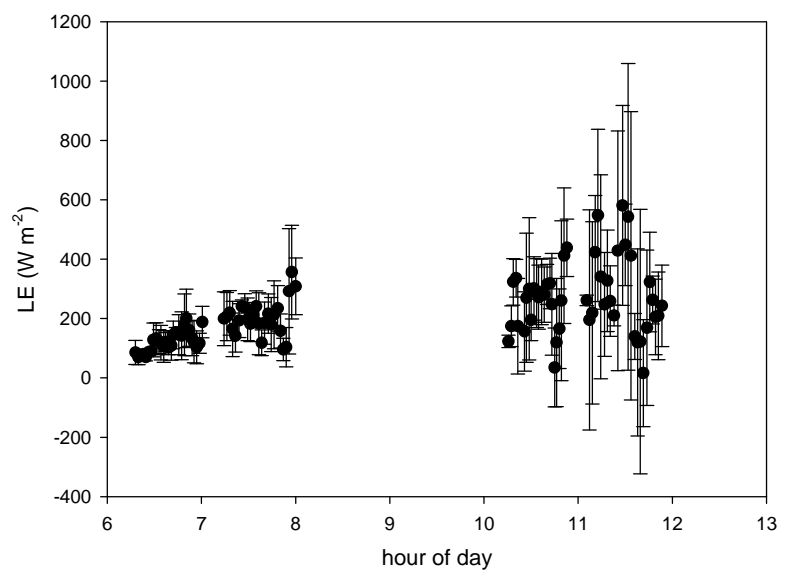

(b)

Airborne observations of $\mathrm{CO}_{2}$ Flux $\left(\mu \mathrm{mol} \mathrm{m} \mathrm{m}^{-2}\right)$ at 16 July 2002

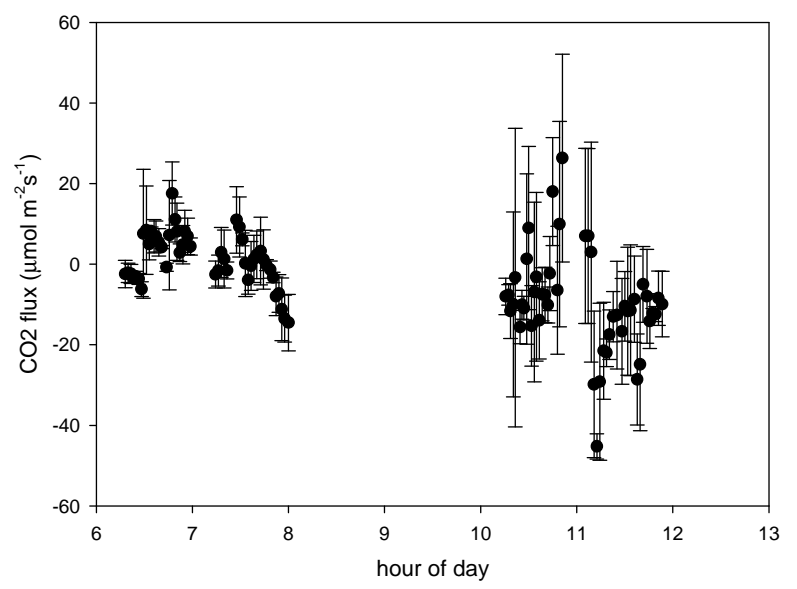

Fig. 11. Airborne observations of latent heat flux $\left(\mathrm{W} \mathrm{m}^{-2}\right)$ and $\mathrm{CO}_{2}$ flux $\left(\mu \mathrm{mol} \mathrm{m} \mathrm{m}^{-2} \mathrm{~s}^{-1}\right.$ ) for 16 July 2002 . The error bars represent the $95 \%$ confidence interval.

Especially mid-day flights around local noon often exhibit an uncertainty estimation that can be larger than the flux itself. For morning and afternoon flights the variation is generally somewhat reduced. Figure 11 shows the typical uncertainty in aircraft observed latent heat and $\mathrm{CO}_{2}$ flux graphically for both flights at 16 July 2002 .

The spatially simulated $\mathrm{CO}_{2}$-fluxes are compared in Fig. 12 with the observations from the aircraft. From the comparison between simulated trends in results and observations a similar pattern can be seen, with a larger uptake for the Veluwe area (beginning and ending of the graph in the lower panel of Fig. 12). The top panel of both figures show absolute values of $\mathrm{CO}_{2}$ fluxes where the blue colour coding reflects the uptake of $\mathrm{CO}_{2}$ by the vegetation and the red colour the release of $\mathrm{CO}_{2}$ through emission or respiration. Simulated spatial variation in $\mathrm{CO}_{2}$-fluxes is dominated by the
Table 6. Averaged $\mathrm{CO}_{2}$ fluxes $\left(\mu \mathrm{mol} \mathrm{m}{ }^{-2} \mathrm{~s}^{-1}\right.$ ) along the flightpath for both flights on 16 July 2002. As in Table 5.

\begin{tabular}{lcrrr}
\hline 16/07 1st flight & I & II & III & entire flightpath \\
\hline average observation & -7.56 & 0.19 & 3.23 & 0.39 \\
average flux atm & -0.59 & 1.45 & 0.71 & 0.70 \\
average flux sfc & -8.74 & -3.07 & -3.51 & -4.27 \\
\hline 16/07 2nd flight & I & II & III & entire flightpath \\
\hline average observation & -7.85 & -9.16 & -8.40 & -8.44 \\
average flux atm & -4.51 & -1.77 & 0.05 & -1.32 \\
average flux sfc & -10.92 & -5.10 & -6.98 & -7.23 \\
\hline
\end{tabular}

contrast between anthropogenic sources over urban areas and biospheric sinks over rural areas. Since the aircraft flight path was obligatory avoiding build-up areas (for safety reasons), it could not capture the largest contrasts in this environment. The landscape feature that is rather consistently resolved in both model and observations and in both latent heat and $\mathrm{CO}_{2}$ fluxes is the large forest area of the Veluwe, located in the eastern part of the domain. Averaged along the flight track (Table 6) we see that the simulated $\mathrm{CO}_{2}$ flux is comparable with the observed flux for the early morning flight. The observations show only a stronger downward flux of $\mathrm{CO}_{2} \mathrm{com}-$ pared to the simulated values above the forested area. This is partly compensated by a stronger simulated downward flux of $\mathrm{CO}_{2}$ above the wet grassland along the rivers. Due to the near-absence of turbulent diffusion in the early morning at levels above the surface both latent heat and $\mathrm{CO}_{2}$ fluxes at flight level are underestimated by the model as is shown by the line graphs in both Figs. 10 and 12. Looking at the trends of $\mathrm{CO}_{2}$-fluxes along the flight path the model captures the various landscape elements with negative fluxes simulated at the end of the return flight of the airplane.

During the field campaign profiles of various variables were measured using an aircraft. Figures 13 and 14 show the comparisons between, respectively, potential temperature $(\mathrm{K})$ and $\mathrm{CO}_{2}$ concentration $(\mathrm{ppm})$ for four timeslots during 16 July when the profiles were measured. The profiles are measured at various locations in central-Netherlands. Comparing potential temperature profiles we can observe that the fit between simulated and observed profiles is improving during the day. The profiles measured in the vicinity of Cabauw (red - morning and blue - afternoon) show that in the morning the lower part of the atmosphere is simulated with lower potential temperature than observed. This is also true for the morning profile measured near the Loobos observational tower. The afternoon profile near Cabauw shows that the potential temperature in the lower atmosphere is simulated in accordance with measurements. The model tends to underestimate potential temperature by $1-2 \mathrm{~K}$ higher up in the planetary boundary layer (PBL). Simulated PBL height on 16 July stays somewhat behind reality - respectively $1200 \mathrm{~m}$ 
(a)
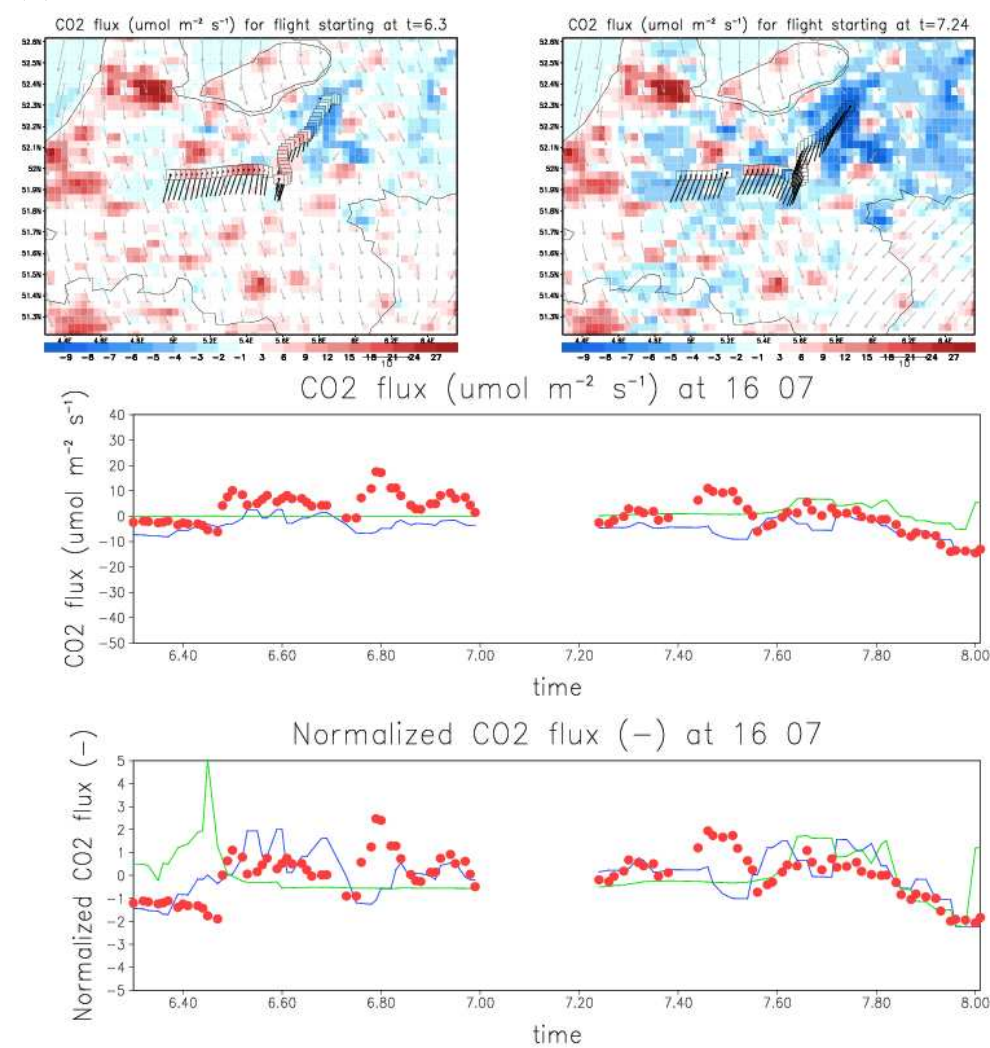

(b)
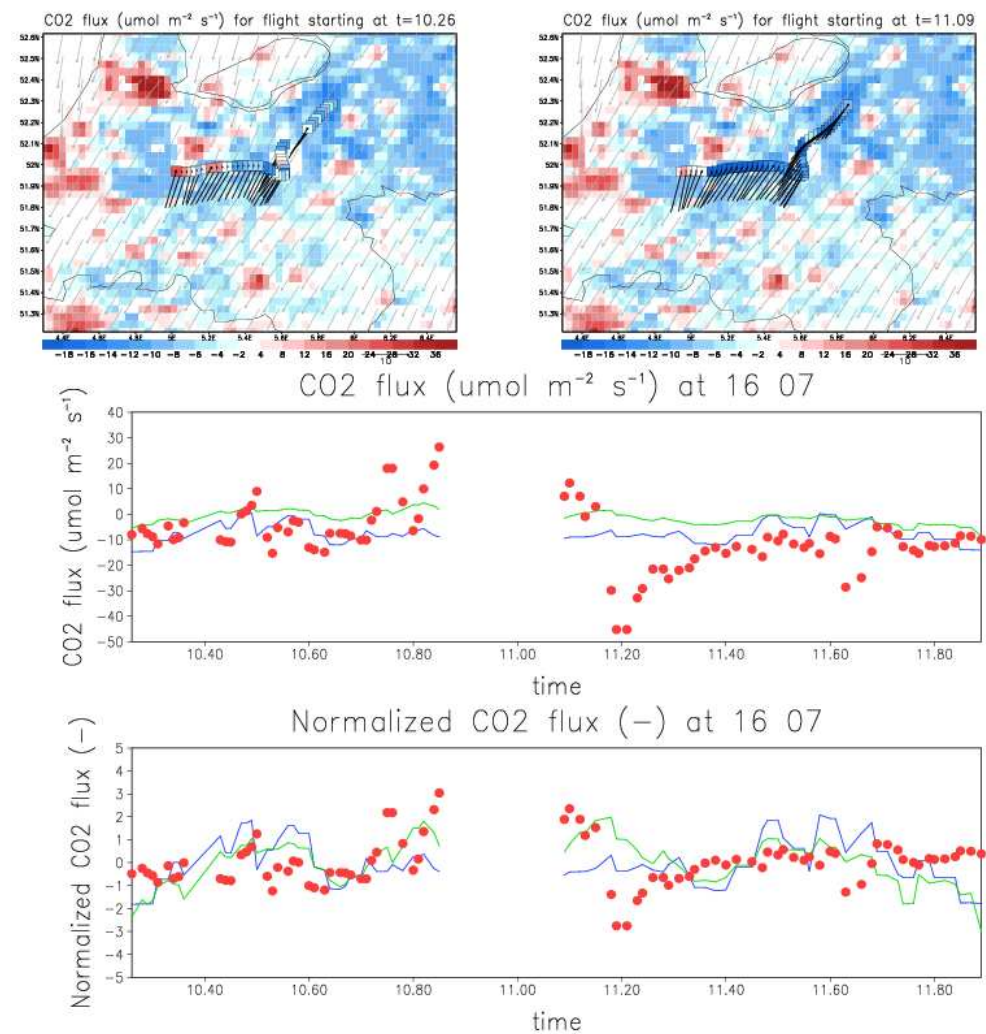

Fig. 12. Spatial comparison of carbon fluxes $\left(\mu \mathrm{mol} \mathrm{m}^{-2} \mathrm{~s}^{-1}\right.$ ) against aircraft observations, for the flights on 16 July $2002-(a)$ : 06:28 UTC, 07:22 UTC; (b): 10:25 UTC, 11:07 UTC. Explanation of the maps is given in the caption accompanying Fig. 10. 
(a)

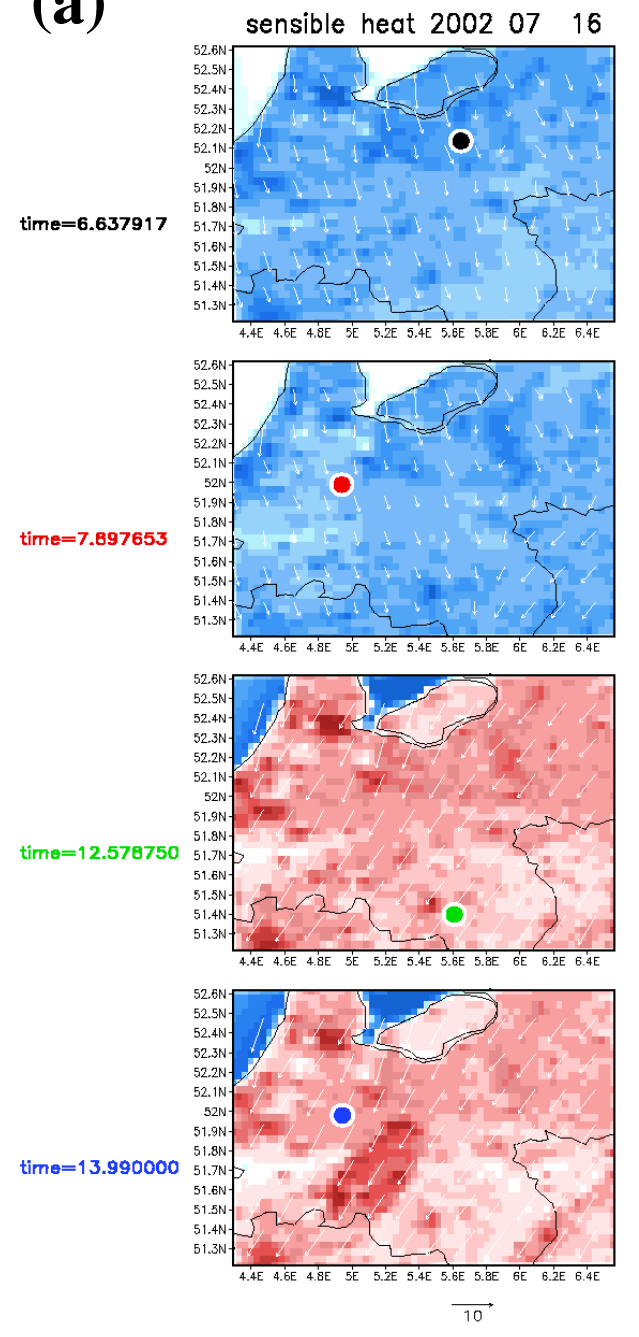

(b)

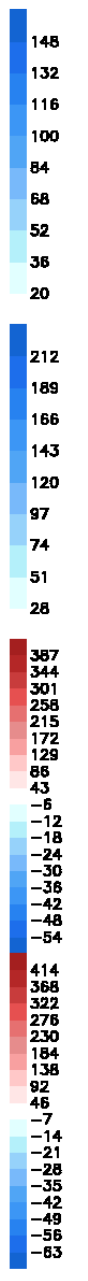

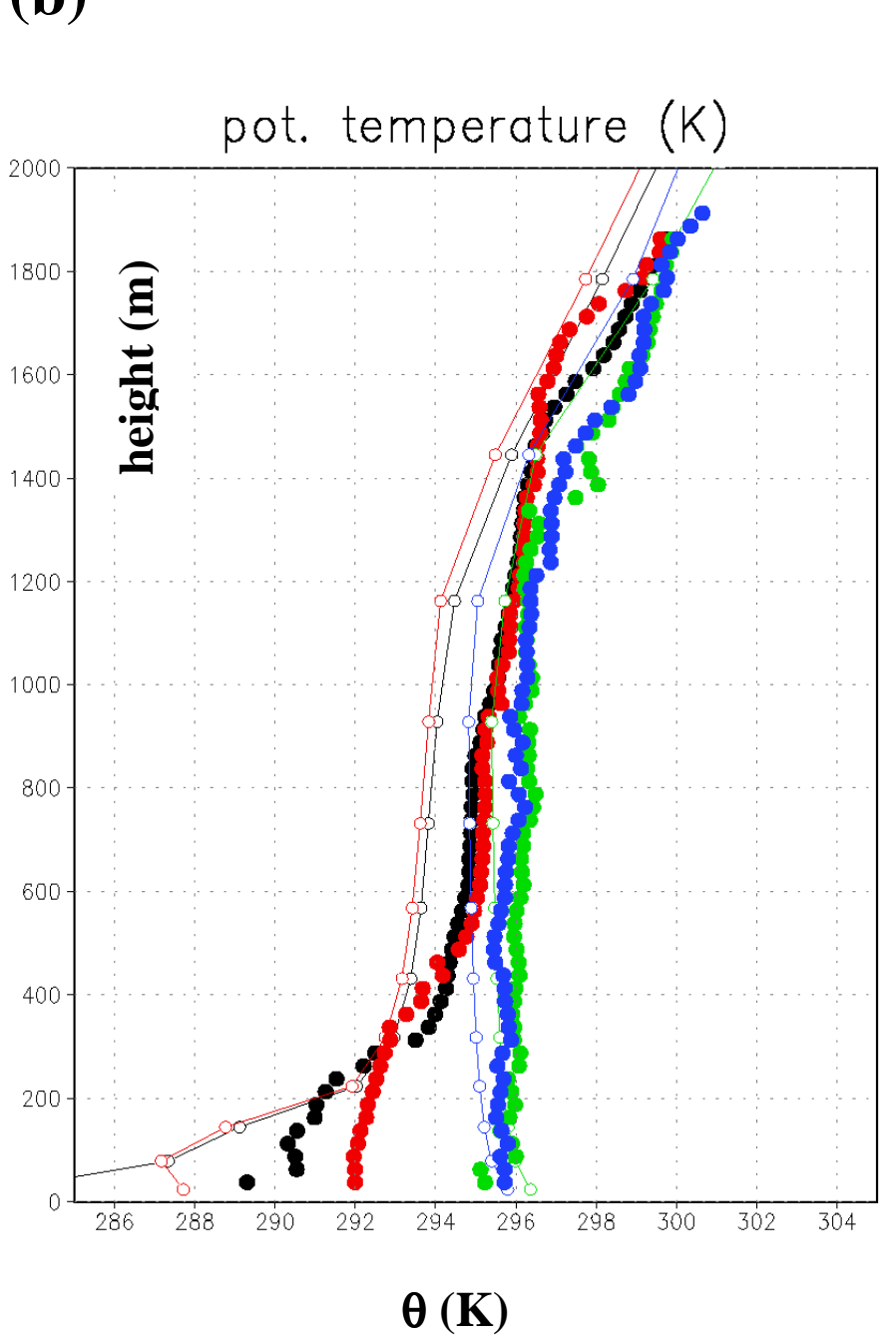

Fig. 13. Comparison of simulated profiles of potential temperature (K) against aircraft observations. (a) Simulated surface sensible heat flux field at time of profile flight, with profile flight locations (coloured dots). (b) Observed profiles (filled dots) and simulated profiles (open circles and lines). Note that the time sequence of the profiles is black, red, green and blue.

vs. $1500 \mathrm{~m}$ maximum. This has its direct effect on simulated $\left[\mathrm{CO}_{2}\right]$ with a lower PBL height leading to higher $\left[\mathrm{CO}_{2}\right]$. Although the concentration is in general overestimated by the model for this particular day, the temporal trends are simulated well by the model with a typical early morning $\left[\mathrm{CO}_{2}\right]$ profile $\left(\mathrm{CO}_{2}\right.$ trapped in the lower part of the atmosphere) developing into a well-mixed profile in the afternoon. Figure 15 shows the time series of the observed and simulated $\left[\mathrm{CO}_{2}\right]$ at the $60 \mathrm{~m}$ level at Cabauw. In general the model captures $\left[\mathrm{CO}_{2}\right]$ dynamics well (i.e. the diurnal range), but on a number of days the simulated $\left[\mathrm{CO}_{2}\right]$ is lower in the simulations than observed, on 17 and 18 mostly during night time, later on more so during daytime. Also on some days a phase lag seems to exist between simulated and observed $\left[\mathrm{CO}_{2}\right]$. These discrepancies may partly be a result of an underes- timated night time respiration by the model, but more likely result from the turbulence parameterization used in the model (Mellor-Yamada). The $\mathrm{CO}_{2}$ concentration near the surface at 17 July is simulated well (not shown here) which does imply that the nighttime and early morning boundary layer is simulated too shallow by the model. The building up and the breaking down of the PBL most probably also leads to the aforementioned phase lag.

\subsection{Sensitivity experiments}

To explore some of the controlling factors that determine $\left[\mathrm{CO}_{2}\right]$ two sensitivity experiments were performed for the first three days of the period. In the first simulation anthropogenic (urban) fluxes were increased by $20 \%$ and in the second simulation a $20 \%$ increase was given to the biogenic 

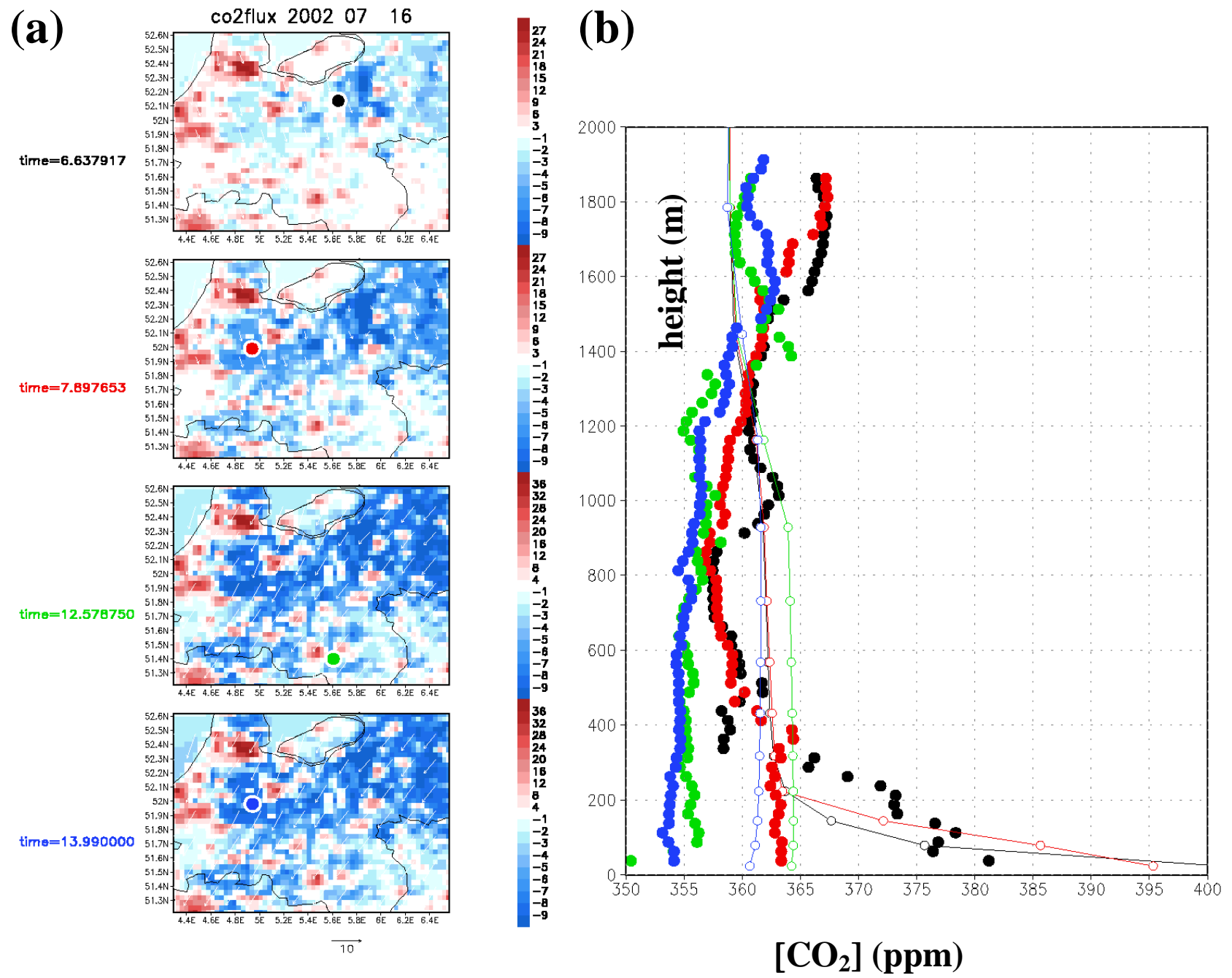

Fig. 14. Comparison of simulated profiles of $\mathrm{CO}_{2}$ concentration (ppm) against aircraft observations. (a) Simulated surface $\mathrm{CO}_{2}$ flux at the time of the profile flight, with profile flight locations (coloured dots), (b) observed profiles (filled dots) and simulated profiles (open circles and lines). Note that the time sequence of the profiles is black, red, green and blue.

(all vegetation classes) fluxes. Both increases are applied on the absolute values of the fluxes. Results of both sensitivity experiments were subsequently compared with the standard experiment. This analysis suggest that the densely populated western part of the Netherlands, is more sensitive to the $20 \%$ change in anthropogenic emissions leading to a change of more than $8 \mathrm{ppm}$ in $\left[\mathrm{CO}_{2}\right]$ near the surface in the anthropogenic sensitivity experiment (Fig. 16). The model simulates this change only close to the surface, limiting the impact to the lower $200 \mathrm{~m}$ of the atmosphere. The relative contribution of the biogenic sources (maximum change: $1.6 \mathrm{ppm}$, not shown) is smaller than the relative contribution of the anthropogenic emissions. The reason for this is that the anthropogenic emissions influence the concentration strongly during night-time, when accumulation is relatively strong due to low PBL heights, while biogenic uptake only takes place during day-time when PBL heights are relatively large and contributions are relatively low. Night-time anthropogenic emissions under the footprint of the tower are strong compared to the biogenic emissions. For the eastern part (surroundings of the Veluwe) the results are different. In the vicinity of the Loobos tower it appears that a $20 \%$ change in both anthropogenic and biogenic fluxes account for an equal change in $\left[\mathrm{CO}_{2}\right]$ of about $2.5 \mathrm{ppm}$ during night time resulting from higher anthropogenic emissions and higher respiration of the forest (Fig. 17). During daytime the change in $\left[\mathrm{CO}_{2}\right]$ at Loobos resulting from different emissions is smaller than at Cabauw. Higher uptake of the forest reduces $\left[\mathrm{CO}_{2}\right]$ as the contribution of a more assimilating forest outweighs that of the few cities on and around the Veluwe. 
CO2 concentration at Cabauw

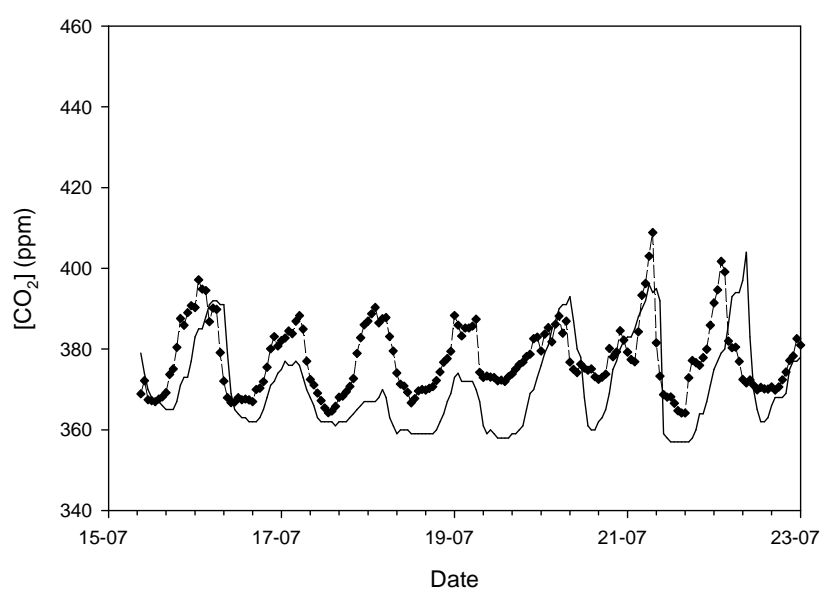

Fig. 15. Comparison of observed and simulated $\left[\mathrm{CO}_{2}\right](\mathrm{ppm})$ at $60 \mathrm{~m}$ for Cabauw. Diamonds and dashed lines: observed values; black lines simulated at a grid point nearest to the observational site.

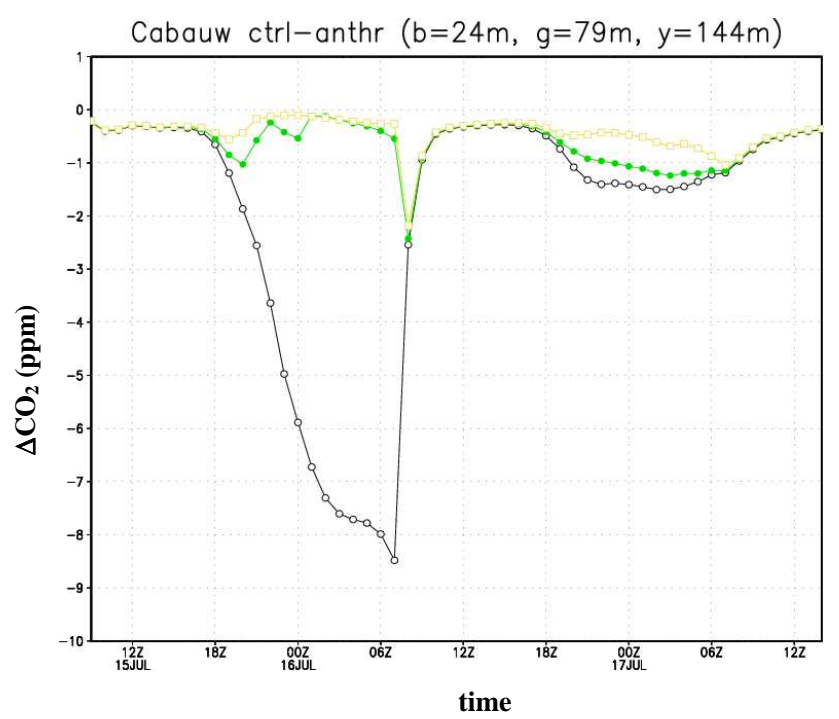

Fig. 16. Difference in simulated $\left[\mathrm{CO}_{2}\right](\mathrm{ppm})$ at Cabauw between the control simulation and the simulation with an increase of $20 \%$ in anthropogenic emissions for three heights: Black: $24 \mathrm{~m}$, green: $79 \mathrm{~m}$, yellow: $144 \mathrm{~m}$

Figure 18 shows the important role that cities play in determining the $\left[\mathrm{CO}_{2}\right]$ in The Netherlands and especially in the western part of the country. It also shows the transport of carbon dioxide in the atmosphere when western winds dominate the regional weather. This figure shows the dispersion of $\left[\mathrm{CO}_{2}\right]$ rich plume originating from the cities over The Netherlands.

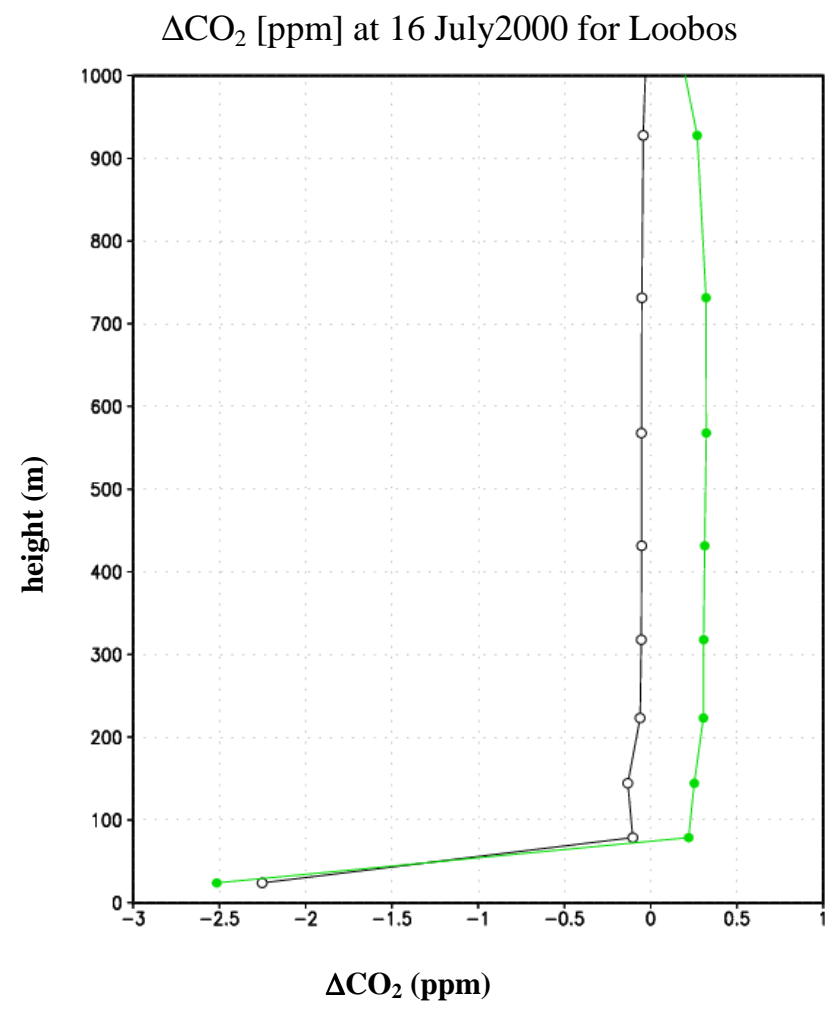

Fig. 17. Vertical profile at Loobos (16 July 2002, 00:00 GMT) of the difference in simulated $\left[\mathrm{CO}_{2}\right](\mathrm{ppm})$ between control simulation and a $20 \%$ increased anthropogenic emissions simulation (black) and between the control simulation and $20 \%$ increased biogenic fluxes simulation (green).

\section{Discussion and conclusions}

In a first attempt to simulate the carbon exchange on a regional scale for a heterogeneous area in The Netherlands, the coupled regional model (RAMS-SWAPS-C) is able to simulate results close to reality, but it also reveals some weaknesses requiring improvement. For the simulated period the comparison between station observations and model output looked very promising for the grass and forest sites. Latent heat flux for the agricultural site was simulated well but it appeared that the $\mathrm{CO}_{2}$ flux, especially photosynthesis, was underestimated significantly due to underestimation of the shortwave radiation and the use of (generic) parameter values in the carbon exchange sub model. The latter asks for observations above various land use types so that parameters that describe, amongst others, the carbon exchange of the vegetation (maize in this case) can be estimated better. This approach was taken during the CERES campaign, which was held in the early summer of 2005 (Dolman et al., 2006), and campaigns which were set up within the framework of the The Netherlands research programme "Climate changes spatial planning" (Kabat et al., 2005). These initiatives will provide the modelling community with a multitude of station observations for various land use types. In addition, land 

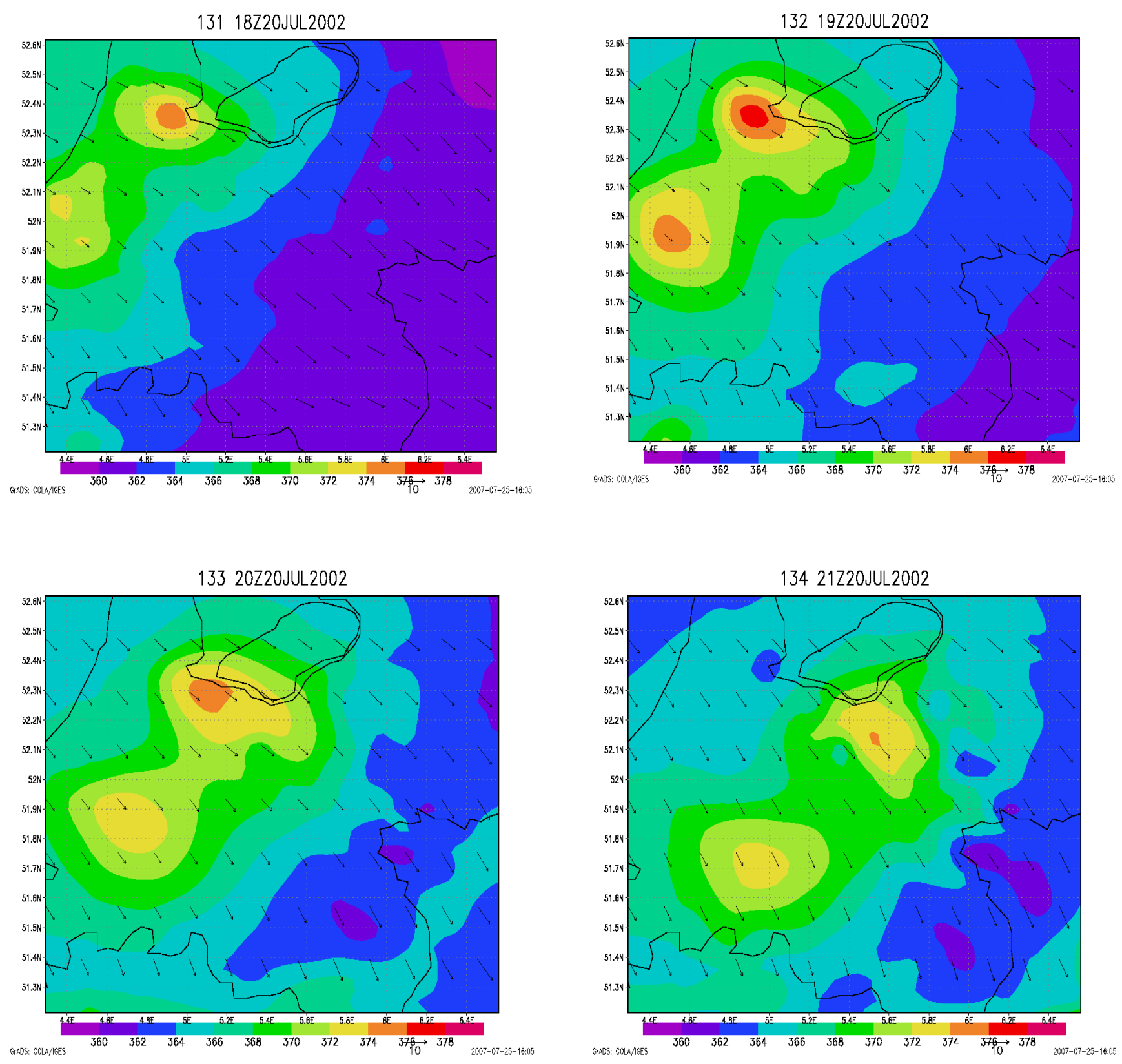

Fig. 18. Example of $\mathrm{CO}_{2}$ transport: snapshots of $\left[\mathrm{CO}_{2}\right]$ (ppm) at the lowest model level for 4 different times on 20 July 2002 (top left bottom right: 18:00 GMT-21:00 GMT with hourly timesteps).

use maps should also account for this vegetation class if the difference with other vegetations is significantly large. During these campaigns observations were also taken in different parts of the year under varying meteorological conditions building on the experiences of the RECAB campaigns. This gives the modelling community an excellent opportunity to improve the calibration and validation of their models. It also helps in investigating the varying dynamics in $\mathrm{CO}_{2}$ dispersion between summer (with active vegetation) and winter (increased importance of anthropogenic emission sources).
Another shortcoming in the comparison between the model and the observations is that the radiation at the surface is underestimated by the model especially in cloudy and unstable conditions. This in turn has its effect on the energy balance at the surface and the simulated $\mathrm{CO}_{2}$ flux. The location and timing of cloud systems appeared to be important during the simulated period as this period of intense measurements was characterized by unstable, windy weather with a multitude of cloud systems of various scales passing over The Netherlands. As might be expected, the model is able 
to capture some of signal caused by the large-scale synoptic patterns, but has problems with the smaller scale features.

The model's performance is assessed given the databases that were ready to implement in the modelling environment. The simulations would be improved if a more realistic fineresolution anthropogenic emissions map was available. Such data in principle are available (but no publicly) at very fine spatial resolutions from the basic inventories. Also for temporal downscaling more detailed approaches exist (Friedrich et al., 2003).

Aircraft observed fluxes of latent heat across the same track during the observational campaign exhibited a very high variability, probably driven more by random errors and non stationary sampling conditions due to large scale turbulence, than by surface heterogeneity. The large scatter in aircraft observed fluxes makes it difficult to properly validate spatially simulated fields of latent heat flux. In this case spatial variations are generally caused by clouds and are larger than variations that can be linked to known surface heterogeneities. Thus a proper simulation of cloud cover dynamic becomes crucial when conditions exhibit a high variability, like in the days of this campaign.

Spatially simulated carbon fluxes were compared against aircraft observations and the results showed that the simulated trends in carbon exchange generally followed the observed trends. However the point by point variation in the two correlated poorly. This is not strange when comparing simulated surface fluxes in the model with those measured higher up by the aircraft. Modelling the footprint area of the aircraft and then comparing the average simulated flux in the footprint to the aircraft observations might overcome this. Approaches in this direction have been developed by e.g. Ogunjemiyo et al. (2003), Hutjes et al. (2010), though Garten et al. (2003) point an important shortcoming in simple footprint models, that would certainly have complicated our study, that is "the inability to predict how quickly real clouds move and redistribute themselves vertically under particular meteorological conditions".

In contrast we (and others, e.g. Sarrat et al., 2007) meant to overcome this footprint mismatch by also comparing simulated fluxes at flight altitude to those observed. However, the simulated absence of turbulent diffusion is apparent as the $\mathrm{CO}_{2}$ fluxes at flight level are close to zero even when a significant uptake at the surface is simulated. This asks for better vertical diffusion schemes in transport models, that simulate vertical flux divergence and entrainment near the boundary layer top more realistically.

The various profiles measured during the first period of the campaign showed that the model underestimates potential temperature especially in the morning. The boundary layer dynamics seem to be reproduced well, though the stable boundary layer in the early morning seems to be simulated too shallow and too cold. Fine scale structures in observed scalar profiles cannot be captured with the current vertical resolution of the model. From the station validation we can also see that during most mornings in the simulation the depletion of $\mathrm{CO}_{2}$ at the lower levels, due to dilution and uptake at the surface, in the model occurs later than in the observations. These issues may all benefit from higher vertical resolution in lower part pof the atmosphere in the model. The validation of the vertical profiles also indicates that the depth of the well-mixed day-time boundary layer is not well represented and is underestimated by $100-200 \mathrm{~m}$ by the model. de Arellano et al. (2004) assessed the importance of the entrainment process for the distribution and evolution of carbon dioxide in the boundary layer. They also showed that the $\mathrm{CO}_{2}$ concentration in the boundary layer is reduced much more effectively by the ventilation with entrained air than by $\mathrm{CO}_{2}$ uptake by the vegetation. In the turbulent parameterization (Mellor-Yamada) of the atmospheric model we found that the entrainment process is poorly represented leading to a higher simulated $\mathrm{CO}_{2}$ concentration in most of the vertical profile. Also the building up and breaking down of the PBL seemed to be difficult to simulate by the present turbulent parameterization. Future model development should focus on turbulence and PBL parameterizations in general and on the entrainment processes in particular.

From the station validation of the $\mathrm{CO}_{2}$ concentration (Fig. 15) the influence of the sea might be an important factor for the concentrations simulated near the coastal strip of The Netherlands. One of the shortcomings of the present modelling system is the coarse resolution of the partial pressure of $\mathrm{CO}_{2}$ within the sea and the values that were derived for the North Sea west and northwest of The Netherlands. According to Hoppema (1991) and Thomas et al. (2004) there is a strong gradient in the North Sea near the Dutch coastal strip with absolute values of the $\mathrm{CO}_{2}$ partial pressure also being more dynamical in time than the values from Takahashi et al. (1997) suggest. Seasonal fields observations show that the North Sea acts as a sink for $\mathrm{CO}_{2}$ throughout the year except for the summer months in the southern region of the North Sea. Figure 5 shows that the modelling system lacks these dynamics in $\delta p \mathrm{CO}_{2}$. As a result in the case of strong winds blowing from west/northwestern directions air with relative low simulated $\left[\mathrm{CO}_{2}\right]$ will penetrate inland compared to the seasonal fields observations in summer months.

The results of the sensitivity experiments showed that the response of $\left[\mathrm{CO}_{2}\right]$ to these surface flux variations is larger at Cabauw than at Loobos and in both cases well above detection limits. However, we also show that the signal is strongest at low levels. We also conclude that it is possible to determine the cause of an observed change in $\mathrm{CO}_{2}$ concentration in terms of sources and sinks in the vicinity of an observational site. This is complementary to the work of Vermeulen et al. (2006) who concluded that "inverse methods (...) are suitable to be applied in deriving independent estimates of greenhouse gas emissions using Source-Receptor relationships." Given this approach an observed change in $\left[\mathrm{CO}_{2}\right]$ can be related to a certain greenhouse gas emission from a certain land use in the vicinity of the observational site. The present 
study also confirms the recommendations given by Geels et al. (2004) for future modeling work of improved high temporal resolution (at least daily) surface biosphere, oceanic and anthropogenic flux estimates as well as high vertical and horizontal spatiotemporal resolution of the driving meteorology. This study suggests that to resolve $20 \%$ flux difference you either need to measure concentrations close to the surface or very precise.

In this paper we tried to analyse some of the factors that control the carbon dioxide concentration for a region covering a large part of The Netherlands. Useful conclusions have been drawn from the use of a regional model coupled to a detailed land-surface model and comparing simulations to various observations ranging from station to aircraft measurements. The region used for this study is characterized by a strongly heterogeneous rural land use alternated with cities/villages of various sizes. The forests at the Veluwe decrease the atmospheric carbon dioxide whereas the emissions from the urbanized areas in The Netherlands increased $\left[\mathrm{CO}_{2}\right]$ transported in plumes. At a larger scale, the influence of the cleaning effect of the sea seemed to be important to simulate the $\left[\mathrm{CO}_{2}\right]$ more realistically. The effect of better representations of the partial pressure-fields of $\mathrm{CO}_{2}$ for the North Sea on the simulated $\left[\mathrm{CO}_{2}\right]$ inland remains a subject needing further research.

The aforementioned campaigns (CERES and "Climate changes spatial planning") will provide an excellent platform for further research, from both observational and modelling perspectives. These initiatives address the uncertainties in the input datasets and model structure and parameters. In part, results will be specific to the region under study but also progress on more general issues is significant, as this special issue demonstrates.

Acknowledgements. This study has been supported by the projects RECAB (EVK2-CT-1999-00034) and CarboEurope-IP project (GOCE-CT2003-505572) funded by the European Commission and by The Netherlands research program "Climate changes Spatial Planning". Furthermore, the authors want to express their thanks to all those, not mentioned before, who worked hard to collect the data in the field: Bert Heusinkveld (Wageningen University, Wageningen, The Netherlands), Wilma Jans and Jan Elbers (Alterra-WUR, Wageningen, The Netherlands). The authors also want to thank Marcus Schumacher, Waldemar Ziegler and Johannes Laubach for providing us with observations of convective boundary layer (CBL) concentrations of $\mathrm{CO}_{2}$ and other greenhouse gases. Acknowledgements also go to Paolo Amico (SkyArrow pilot), Alessandro Zaldei and Biagio de Martino (IBIMET technicians). ECMWF is acknowledged for providing meteorological analysis and reanalysis data.

Edited by: A. Arneth

\section{References}

Ashby, M.: Modelling the water and energy balances of Amazonian rainforest and pasture using Anglo-Brazilian Amazonian climate observation study data, Agr. Forest Meteorol., 94, 79-101, 1999.

Bakwin, P. S., Tans, P. P., Zhao, C. L., Ussler, W., and Quesnell, E.: Measurements of Carbon-Dioxide on a Very Tall Tower, Tellus B, 47, 535-549, 1995.

Betts, A. K., Desjardins, R. L., and Macpherson, J. I.: Budget Analysis of the Boundary-Layer Grid Flights During Fife 1987, J. Geophys. Res.-Atmos., 97, 18533-18546, 1992.

Collatz, G. J., Ribas Carbo, M., and Berry, J. A.: Coupled photosynthesis-stomatal conductance model for leaves of C4 plants, East Melbourne : Commonwealth Scientific and Industrial Research Organization, Aust. J. Plant Physiol., 19, 519539, 1992.

Cotton, W. R., Pielke, R. A., Walko, R. L., Liston, G. E., Tremback, C. J., Jiang, H., McAnelly, R. L., Harrington, J. Y., Nicholls, M. E., Carrio, G. G., and McFadden, J. P.: RAMS 2001: Current status and future directions, Meteorol. Atmos. Phys., 82, 5-29, 2003.

Culf, A. D., Fisch, G., Malhi, Y., and Nobre, C. A.: The influence of the atmospheric boundary layer on carbon dioxide concentrations over a tropical forest, Agr. Forest Meteorol., 85, 149-158, 1997.

de Arellano, J. V. G., Gioli, B., Miglietta, F., Jonker, H. J. J., Baltink, H. K., Hutjes, R. W. A., and Holtslag, A. A. M.: Entrainment process of carbon dioxide in the atmospheric boundary layer, J. Geophys. Res.-Atmos., 109, D18110, doi:10.1029/2004JD004725, 2004.

Denning, A. S., Fung, I. Y., and Randall, D.: Latitudinal Gradient of Atmospheric $\mathrm{CO}_{2}$ Due to Seasonal Exchange with Land Biota, Nature, 376, 240-243, 1995.

Denning, A. S., Takahashi, T., and Friedlingstein, P.: Can a strong atmospheric $\mathrm{CO}_{2}$ rectifier effect be reconciled with a "reasonable" carbon budget?, Tellus B, 51, 249-253, 1999.

Derwent, R. G., Ryall, D. B., Manning, A., Simmonds, P. G., O’Doherty, S., Biraud, S., Ciais, P., Ramonet, M., and Jennings, S. G.: Continuous observations of carbon dioxide at Mace Head, Ireland from 1995 to 1999 and its net European ecosystem exchange, Atmos. Environ., 36, 2799-2807, 2002.

Dolman, A. J.: A Multiple-Source Land-Surface Energy-Balance Model for Use in General-Circulation Models, Agr. Forest Meteorol., 65, 21-45, 1993.

Dolman, A. J., Noilhan, J., Durand, P., Sarrat, C., Brut, A., Piguet, B., Butet, A., Jarosz, N., Brunet, Y., Loustau, D., Lamaud, E., Tolk, L., Ronda, R., Miglietta, F., Gioli, B., Magliulo, V., Esposito, M., Gerbig, C., Korner, S., Glademard, R., Ramonet, M., Ciais, P., Neininger, B., Hutjes, R. W. A., Elbers, J. A., Macatangay, R., Schrems, O., Perez-Landa, G., Sanz, M. J., Scholz, Y., Facon, G., Ceschia, E., and Beziat, P.: The CarboEurope regional experiment strategy, B. Am. Meteorol. Soc., 87, 13671379, 2006.

Flatau, P. J., Tripoli, G. J., Verlinde, J., and Cotton, W. R.: The CSU-RAMS cloud microphysical module: General theory and code documentation, Colorado State Univ., Fort Collins, Colorado, 451, 88, 1989.

Friedrich, R., Freibauer, A., Gallmann, E., Giannouli, M., Koch, D., Peylin, P., Pye, S., Riviere, E., Jose, R. S., Winiwarter, W., Blank, P., Kühlwein, J., Pregger, T., Reis, S., Scholz, Y., Theloke, 
J., and Vabitsch, A.: Temporal and Spatial Resolution of Greenhouse Gas Emissions in Europe, MPI fuer Biogeochemie, Jena, 36, 2003.

Garten, J. F., Schemm, C. E., and Croucher, A. R.: Modeling the transport and dispersion of airborne contaminants: A review of techniques and approaches, J. Hopkins Apl. Tech. D., 24, 368375, 2003.

Geels, C., Doney, S. C., Dargaville, R., Brandt, J., and Christensen, J. H.: Investigating the sources of synoptic variability in atmospheric $\mathrm{CO}_{2}$ measurements over the Northern Hemisphere continents: a regional model study, Tellus B, 56, 35-50, 2004.

Gerbig, C., Lin, J. C., Wofsy, S. C., Daube, B. C., Andrews, A. E., Stephens, B. B., Bakwin, P. S., and Grainger, C. A.: Toward constraining regional-scale fluxes of $\mathrm{CO}_{2}$ with atmospheric observations over a continent: 2. Analysis of COBRA data using a receptor-oriented framework, J. Geophys. Res., 108(D24), 4757, doi:10.1029/2003JD003770, 2003.

Gioli, B., Miglietta, F., De Martino, B., Hutjes, R. W. A., Dolman, H. A. J., Lindroth, A., Schumacher, M., Sanz, M. J., Manca, G., Peressotti, A., and Dumas, E. J.: Comparison between tower and aircraft-based eddy covariance fluxes in five European regions, Agr. Forest Meteorol., 127, 1-16, 2004.

Global Soil Data Task Group: Global Gridded Surfaces of Selected Soil Characteristics (IGBP-DIS), Global Gridded Surfaces of Selected Soil Characteristics (International Geosphere-Biosphere Programme - Data and Information System), Data set, available on-line: http://www.daac.ornl.gov, last access: July 2010, from Oak Ridge National Laboratory Distributed Active Archive Center, Oak Ridge, Tennessee, USA, 2000.

Gurney, K. R., Law, R. M., Denning, A. S., Rayner, P. J., Baker, D., Bousquet, P., Bruhwiler, L., Chen, Y. H., Ciais, P., Fan, S., Fung, I. Y., Gloor, M., Heimann, M., Higuchi, K., John, J., Maki, T., Maksyutov, S., Masarie, K., Peylin, P., Prather, M., Pak, B. C., Randerson, J., Sarmiento, J., Taguchi, S., Takahashi, T., and Yuen, C. W.: Towards robust regional estimates of $\mathrm{CO}_{2}$ sources and sinks using atmospheric transport models, Nature, 415, 626630, 2002.

Hanan, N. P., Kabat, P., Dolman, A. J., and Elbers, J. A.: Photosynthesis and carbon balance of a Sahelian fallow savanna, Global Change Biol., 4, 523-538, 1998.

Hanan, N. P.: Enhanced two-layer radiative transfer scheme for a land surface model with a discontinuous upper canopy, Agr. Forest Meteorol., 109, 265-281, 2001.

Harrington, J. Y.: The effects of radiative and microphysical processes on simulated warm and transition season Arctic stratus, PhD Diss., Atmospheric Science Paper No 637, Colorado State University, Department of Atmospheric Science, Fort Collins, CO 80523, USA, 289 pp., 1997.

Hoppema, J. M. J.: The Seasonal Behavior of Carbon-Dioxide and Oxygen in the Coastal North-Sea Along the Netherlands, Neth. J. Sea Res., 28, 167-179, 1991.

Hutjes, R. W. A., Vellinga, O. S., Gioli, B., and Miglietta, F.: Disaggregation of airborne flux measurements using footprint analysis, Agr. Forest Meteorol., 150, 966-983, 2010

Janssens, I. A., Freibauer, A., Ciais, P., Smith, P., Nabuurs, G. J., Folberth, G., Schlamadinger, B., Hutjes, R. W. A., Ceulemans, R., Schulze, E. D., Valentini, R., and Dolman, A. J.: Europe's terrestrial biosphere absorbs 7 to $12 \%$ of European anthropogenic $\mathrm{CO}_{2}$ emissions, Science, 300, 1538-1542, 2003.
Kabat, P., Hutjes, R. W. A., and Feddes, R. A.: The scaling characteristics of soil parameters: From plot scale heterogeneity to subgrid parameterization, J. Hydrol., 190, 363-396, 1997.

Kabat, P., van Vierssen, W., Veraart, J., Vellinga, P., and Aerts, J.: Climate proofing the Netherlands, Nature, 438, 283-284, 2005.

Knorr, W.: Annual and interannual $\mathrm{CO}_{2}$ exchanges of the terrestrial biosphere: process-based simulations and uncertainties, in: GTCE-LUCC Special Section: Papers resulting from the Joint Open Science Conference of the IGBP Global Change and Terrestrial Ecosystems Project and the IGBP-IHDP Land Use and Cover Change Project, held in Barcelona, Spain, March 1998, 224, 225-252, 2000.

Kuhlwein, J., Wickert, B., Trukenmuller, A., Theloke, J., and Friedrich, R.: Emission-modelling in high spatial and temporal resolution and calculation of pollutant concentrations for comparisons with measured concentrations, Atmos. Environ., 36, S7-S18, 2002.

Lloyd, J., Grace, J., Miranda, A. C., Meir, P., Wong, S. C., Miranda, H. S., Wright, I. R., Gash, J. H. C., and McIntyre, J.: A simple calibrated model of Amazon rainforest productivity based on leaf biochemical properties, Plant cell environ., Oxford, Blackwell Scientific Publishers, October 1995, 18, 1129-1145, 1995.

Mahrt, L., Vickers, D., and Sun, J. L.: Spatial variations of surface moisture flux from aircraft data, Adv. Water Resour., 24, 11331141, 2001.

Marquardt, D. W.: An Algorithm For Least-Squares Estimation Of Nonlinear Parameters, J. Soc. Ind. Appl. Math., 11, 431-441, 1963.

Mellor, G. L. and Yamada, T.: Development of a turbulence closure model for geophysical fluid problems, Rev. Geophys. Space Ge., 20, 851-875, 1982.

Mücher, C. A., Champeaux, J. L., Steinnocher, K. T., Griguola, S., Wester, K., Heunks, C., Winiwater, W., Kressler, F. P., Goutorbe, J. P., Ten Brink, B., Van Katwijk, V. F., Furberg, O., Perdigao, V., and Nieuwenhuis, G. J. A.: Development of a consistent methodology to derive land cover information on a European scale from Remote Sensing for environmental monitoring : the PELCOM report, Alterra Green World Research, Wageningen, 1568-1874, 2001.

Ogink-Hendriks, M. J.: Modeling surface conductance and transpiratio of an oak forest in The Netherlands, Agr. Forest Meteorol., 74, 99-118, 1995.

Ogunjemiyo, S. O., Kaharabata, S. K., Schuepp, P. H., MacPherson, I. J., Desjardins, R. L., and Roberts, D. A.: Methods of estimating $\mathrm{CO}_{2}$, latent heat and sensible heat fluxes from estimates of land cover fractions in the flux footprint, Agr. Forest Meteorol., 117, 125-144, doi:10.1016/s0168-1923(03)00061-3, 2003.

Olivier, J. G. J. and Berdowski, J. J. M.: Global emissions sources and sinks, in: The Climate System, edited by: Berdowski, J. J. M., Guicherit, R., and Heij, B. J., A. A. Balkema Publishers/Swets \& Zeitlinger Publisher, Lisse, 33-78, 2001.

Pérez-Landa, G., Ciais, P., Gangoiti, G., Palau, J. L., Carrara, A., Gioli, B., Miglietta, F., Schumacher, M., Millán, M. M., and Sanz, M. J.: Mesoscale circulations over complex terrain in the Valencia coastal region, Spain - Part 2: Modeling $\mathrm{CO}_{2}$ transport using idealized surface fluxes, Atmos. Chem. Phys., 7, 18511868, doi:10.5194/acp-7-1851-2007, 2007a. 
Pérez-Landa, G., Ciais, P., Sanz, M. J., Gioli, B., Miglietta, F., Palau, J. L., Gangoiti, G., and Millán, M. M.: Mesoscale circulations over complex terrain in the Valencia coastal region, Spain Part 1: Simulation of diurnal circulation regimes, Atmos. Chem. Phys., 7, 1835-1849, doi:10.5194/acp-7-1835-2007, 2007.

Pielke, R. A., Cotton, W. R., Walko, R. L., Tremback, C. J., Lyons, W. A., Grasso, L. D., Nicholls, M. E., Moran, M. D., Wesley, D. A., Lee, T. J., and Copeland, J. H.: A Comprehensive Meteorological Modeling System - Rams, Meteorol. Atmos. Phys., 49, 69-91, 1992.

Rayner, N. A., Parker, D. E., Horton, E. B., Folland, C. K., Alexander, L. V., Rowell, D. P., Kent, E. C., and Kaplan, A.: Global analyses of sea surface temperature, sea ice, and night marine air temperature since the late nineteenth century, J. Geophys. Res., 108(D14), 4407, doi:10.1029/2002JD002670, 2003

Sarrat, C., Noilhan, J., Lacarrere, P., Donier, S., Lac, C., Calvet, J. C., Dolman, A. J., Gerbig, C., Neininger, B., Ciais, P., Paris, J. D., Boumard, F., Ramonet, M., and Butet, A.: Atmospheric $\mathrm{CO}_{2}$ modeling at the regional scale: Application to the CarboEurope Regional Experiment, J. Geophys. Res.-Atmos., 112, D12105, doi:10.1029/2006JD008107, 2007.

Soet, M., Ronda, R. J., Stricker, J. N. M., and Dolman, A. J.: Land surface scheme conceptualisation and parameter values for three sites with contrasting soils and climate, Hydrol. Earth Syst. Sci., 4, 283-294, doi:10.5194/hess-4-283-2000, 2000.

Spieksma, J. F. M., Moors, E. J., Dolman, A. J., and Schouwenaars, J. M.: Modelling evaporation from a drained and rewetted peatland, J. Hydrol., 199, 252-271, 1997.

Takahashi, T., Feely, R. A., Weiss, R. F., Wanninkhof, R. H., Chipman, D. W., Sutherland, S. C., and Takahashi, T. T.: Global airsea flux of $\mathrm{CO}_{2}$ : An estimate based on measurements of seaair $p \mathrm{CO}(2)$ difference, P. Natl. Acad. Sci. USA, 94, 8292-8299, 1997.
Thomas, H., Bozec, Y., Elkalay, K., and de Baar, H. J. W.: Enhanced open ocean storage of $\mathrm{CO}_{2}$ from shelf sea pumping, Science, 304, 1005-1008, 2004.

Valentini, R., Matteucci, G., Dolman, A. J., Schulze, E. D., Rebmann, C., Moors, E. J., Granier, A., Gross, P., Jensen, N. O., Pilegaard, K., Lindroth, A., Grelle, A., Bernhofer, C., Grunwald, T., Aubinet, M., Ceulemans, R., Kowalski, A. S., Vesala, T., Rannik, Ü., Berbigier, P., Loustau, D., Guomundsson, J., Thorgeirsson, H., Ibrom, A., Morgenstern, K., Clement, R., Moncrieff, J., Montagnani, L., Minerbi, S., and Jarvis, P. G.: Respiration as the main determinant of carbon balance in European forests, Nature, 404, 861-865, 2000.

Van Wijk, M. T., Dekker, S. C., Bouten, W., Bosveld, F. C., Kohsiek, W., Kramer, K., and Mohren, G. M. J.: Modeling daily gas exchange of a Douglas-fir forest: comparison of three stomatal conductance models with and without a soil water stress function, Tree Physiol., 20, 115-122, 2000.

Vermeulen, A. T., Pieterse, G., Hensen, A., van den Bulk, W. C. M., and Erisman, J. W.: COMET: a Lagrangian transport model for greenhouse gas emission estimation - forward model technique and performance for methane, Atmos. Chem. Phys. Discuss., 6, 8727-8779, doi:10.5194/acpd-6-8727-2006, 2006.

Wanninkhof, R.: Relationship between Wind-Speed and GasExchange over the Ocean, J. Geophys. Res.-Oceans, 97, 73737382, 1992.

Weiss, R. F.: Carbon dioxide in water and seawater: the solubility of a non-ideal gas, Mar. Chem., 2, 203-215, 1974.

Wickert, B.: Berechnung anthropogener Emissionen in Deutschland für Ozonsimulation - Modellentwicklung und Sensitivitätsstudien, PhD-thesis, Universität Stuttgart, Institut für Energiewirtschaft und Rationelle, 2001. 